\title{
Species-specific behavioral patterns correlate with differences in synaptic connections between homologous mechanosensory neurons
}

\author{
Michael J. Baltzley • Quentin Gaudry • \\ William B. Kristan Jr.
}

Received: 4 November 2009 / Revised: 2 January 2010 / Accepted: 4 January 2010 / Published online: 5 February 2010

(C) The Author(s) 2010. This article is published with open access at Springerlink.com

\begin{abstract}
We characterized the behavioral responses of two leech species, Hirudo verbana and Erpobdella obscura, to mechanical skin stimulation and examined the interactions between the pressure mechanosensory neurons ( $\mathrm{P}$ cells) that innervate the skin. To quantify behavioral responses, we stimulated both intact leeches and isolated body wall preparations from the two species. In response to mechanical stimulation, Hirudo showed local bending behavior, in which the body wall shortened only on the side of the stimulation. Erpobdella, in contrast, contracted both sides of the body in response to touch. To investigate the neuronal basis for this behavioral difference, we studied the interactions between P cells. Each midbody ganglion has four P cells; each cell innervates a different quadrant of the body wall. Consistent with local bending, activating any one P cell in Hirudo elicited polysynaptic inhibitory potentials in the other P cells. In contrast, the P cells in Erpobdella had excitatory polysynaptic connections, consistent with the segment-wide contraction observed in this species. In addition, activating individual $P$ cells caused asymmetrical body wall contractions in Hirudo and symmetrical body wall contractions in Erpobdella. These results suggest that
\end{abstract}

M. J. Baltzley · W. B. Kristan Jr.

Division of Biological Sciences, University of California, San Diego, 3119 Pacific Hall, 9500 Gilman Drive,

\#0357, La Jolla, CA 92093-0357, USA

M. J. Baltzley $(\square)$

Department of Biology, St. Mary's College of Maryland, 18952 E. Fisher Road, St. Mary's City, MD 20686-3001, USA

e-mail: mjbaltzley@smcm.edu

Q. Gaudry · W. B. Kristan Jr.

Department of Neurosciences,

University of California, San Diego, 3119 Pacific Hall,

9500 Gilman Drive, \#0357, La Jolla, CA 92093-0357, USA the different behavioral responses in Erpobdella and Hir$u d o$ are partly mediated by interactions among mechanosensory cells.

Keywords Mechanosensory - Behavior - Evolution · Hirudo $\cdot$ Erpobdella
Abbreviations
DP nerve Dorsal posterior nerve
ED Embryonic development
LBI Local bend interneurons
$\mathrm{N}$ cell Nociceptive neuron
$\mathrm{P}$ cell Pressure mechanosensory neuron
$\mathrm{P}_{\mathrm{D}} \quad$ Dorsal $\mathrm{P}$ cell
$\mathrm{P}_{\mathrm{V}} \quad$ Ventral $\mathrm{P}$ cell
$\mathrm{P}_{\text {POST }} \quad$ Postsynaptic $\mathrm{P}$ cell
$\mathrm{P}_{\mathrm{PRE}} \quad$ Presynaptic $\mathrm{P}$ cell
T cell Touch mechanosensory neuron

\section{Introduction}

Mechanosensory neurons have been studied in a wide range of animals, including crabs (Beenhakker et al. 2004), grasshoppers (Hustert et al. 1999), round worms (Kindt et al. 2007), mice (Suzuki et al. 2003) and humans (Cauna and Ross 1960). Although the neural circuitry underlying mechanically elicited behaviors in various species has also been investigated (Nobili et al. 1998; Hill and Blagburn 1998; Antonsen et al. 2005), we do not understand how these neural circuits have evolved. For example, studies of central pattern generators underlying species-specific behaviors have shown that neural circuits with conserved synaptic connections can produce different outputs simply by changing neuromodulatory input (Fenelon et al. 2004; Newcomb and Katz 
2007). Species-specific behavioral patterns can also occur due to changing synaptic strengths (Chiang et al. 2006) or changing the morphology of neurons (Dacks et al. 2006). As species-specific behaviors evolve, are there rules governing how mechanosensory input typically changes? Is mechanosensory input mediated by changing neuromodulation, lateral interactions, synaptic strengths, or synaptic connections? In this study, we examined the interactions between the pressure mechanosensory neurons (P cells) in the leeches Hirudo verbana and Erpobdella obscura and correlated these interactions with differences in behavioral responses. Our results suggest that simple changes in the interactions between sensory neurons may be responsible for significant differences in behavior in these two leech species.

Each segmental ganglion in Hirudo has four P cells that innervate overlapping quadrants of the body wall (Nicholls and Baylor 1968; Lewis and Kristan 1998a; Thomson and Kristan 2006). Each $P_{V}$ cell innervates roughly half of the ventral body wall and each $P_{D}$ cell innervates roughly half of the dorsal body wall. The P cells in Hirudo mediate a stereotyped behavior called 'local bending' (Kristan 1982; Kristan et al. 1982, 2005; Baca et al. 2008). Local bending is elicited by stimulation of an individual $\mathrm{P}$ cell which causes a combination of excitation and inhibition in the local bend interneurons (LBIs) (Lockery and Kristan 1990b; Baca et al. 2008). The LBIs in turn synapse onto a group of motor neurons. Differing synaptic strengths of the $P$ cells onto the LBIs, as well as inhibitory interactions between motor neurons, produce a contraction of longitudinal muscles in the body wall area innervated by the stimulated $\mathrm{P}$ cell and a relaxation in the adjacent regions of the body wall (Lockery and Kristan 1990a, b).

Many novel behaviors have arisen within the leeches, including predatory behavior in clades with sanguivorous ancestors, swimming in clades with terrestrial ancestors, and terrestrial cocoon deposition in clades with fully aquatic ancestors (Borda and Siddall 2004a, b). Despite these differences in behaviors, the structure of leech midbody ganglia is highly conserved across the entire clade, thereby simplifying the task of identifying homologous neurons (Lent and Frazer 1977; Kramer and Goldman 1981; Nusbaum 1986; Nusbaum and Kristan 1986; Nusbaum et al. 1987; Elsas et al. 1995). Homologous neurons across species are identified based on cell size, location, morphology and physiology (Weiss and Kupfermann 1976; Nusbaum and Kristan 1986; Croll 1987; Watson and Willows 1992; Breidbach and Kutsch 1995; Wright et al. 1996; Katz et al. 2001; Newcomb and Katz 2007). P cell homologs have been previously characterized in a basal leech, Haementeria ghilianii (Kramer and Stent 1985; Kramer et al. 1985), so they are likely present in all leeches.

The arhynchobdellids are a monophyletic clade of leeches that is subdivided into two groups: the Erpobdelliformes, which include E. obscura, and the Hirudiniformes, which include H. verbana (Siddall 2002; Borda and Siddall 2004a, b; Phillips and Siddall 2009). Among the Hirudiniformes, the neural circuitry underlying behavioral patterns of $H$. verbana have been studied extensively (Kristan et al. 2005). In selecting an Erpobdelliform species for comparison with Hirudo, E. obscura was the obvious choice because the adults are large ( $2-3 \mathrm{~g})$ compared to the other Erpobdelliform leeches and are similar in size to adult H. verbana (2-7 g) (Peterson 1983; Wilkin and Scofield 1991; Siddall 2002). Due to the phylogenetic distance between the species, we expected to find behavioral differences between the animals that would be reflected in differences in the underlying neural circuitry.

In order to identify different behavioral patterns in Hirudo and Erpobdella, we first stimulated intact leeches and isolated body wall preparations. We found that the two species have different behavioral responses to mechanical stimulation of the skin. Hirudo contracts only those longitudinal muscles ipsilateral to the site of stimulation, whereas Erpobdella contracts longitudinal muscles around the entire stimulated segment. We found that these differences in behavior are correlated with differences in the synaptic connections between the P cells. In Hirudo, the P cells are mutually inhibitory, which may aid in localizing the behavioral response to the stimulus site. In Erpobdella, the $\mathrm{P}$ cells are mutually excitatory and a localized stimulus results in a segment-wide contraction. This evidence suggests that one mechanism that produces behavioral differences in Hirudo and Erpobdella is this difference in interactions among one set of mechanosensory neurons.

\section{Methods}

Leech care

We obtained adult $H$. verbana from Carolina Biological Supply Co. (Burlington, NC) and Leeches USA (Westbury, NY); these leeches were previously misidentified as Hirudo medicinalis (Kutschera 2006; Siddall et al. 2007). We collected E. obscura in ponds near Lake Itasca, MN and obtained others from Vados Bait Express (Spring Lake Park, MN). Both species were kept at $15^{\circ} \mathrm{C}$ on a $12 \mathrm{~h}$ light/ dark cycle. Hirudo were maintained in five gallon aquaria containing Instant Ocean Sea Salt (Aquarium Systems, Mentor, $\mathrm{OH}$ ) diluted 1:1,000 with deionized water. We kept Hirudo for at least 4 weeks without feeding. Hirudo are sanguivores that take massive blood meals; from experience, the physiological properties of Hirudo ganglia are different for 2-3 weeks after feeding. Erpobdella were kept in five gallon aquaria containing a solution of $90 \mu \mathrm{M} \mathrm{CaCl}_{2}$, $65 \mu \mathrm{M} \quad \mathrm{MgCl}_{2}, \quad 479 \mu \mathrm{M} \mathrm{NaCl}, \quad 67 \mu \mathrm{M} \quad \mathrm{KCl}, \quad 34 \mu \mathrm{M}$ 
$\mathrm{Ca}\left(\mathrm{NO}_{3}\right)_{2}, 10 \mu \mathrm{M} \mathrm{MgSO}{ }_{4}$, and $1 \mathrm{mM}$ Hepes in deionized water. Erpobdella were fed beef liver every 3-4 days.

\section{Intact leech behavior}

We elicited behavioral responses from intact animals by shocking them between midbody segments $8-12$ with a handheld electrode that activates touch ( $\mathrm{T}$ cell) and pressure (P cell) mechanoreceptors, thus mimicking mechanical stimulation (Kristan 1982; Misell et al. 1998). The electrode terminals were two 0.008 inch diameter silver wires separated by about $1 \mathrm{~mm}$. We used a Grass Instruments S88 Dual Channel Stimulator with a Grass Stimulus Isolation Unit (Astro-Med Inc., West Warwick, RI) to deliver $8 \mathrm{~V}, 1 \mathrm{~ms}$ pulses at $10 \mathrm{~Hz}$ in trains that lasted approximately $1 \mathrm{~s}$. Each leech was stimulated five times at intervals of $3 \mathrm{~min}$ or longer.

We divided the behavioral responses into six categories: tensing, local bending, whole-body bending, crawling, swimming, and shortening. Swimming, crawling, shortening, and local bending are well-characterized behaviors in Hirudo (Kristan et al. 1974, 1982, 2005; Stern-Tomlinson et al. 1986; Misell et al. 1998; Puhl and Mesce 2008). We categorized the behavioral response as 'tensing' when a contraction occurred symmetrically across several segments, as 'local bending' when a lateral contraction occurred ipsilaterally to the stimulation site and was restricted to a few segments, and as 'whole-body bending' when a dorsal or ventral contraction caused the leech to form a ' $\mathrm{C}$ ' shape.

Because our data did not form a normal distribution, we transformed them before performing statistical tests. For a behavioral response that occurred $x$ times in $y$ trials, we transformed the data using the formula $\arcsin (\sqrt{ }((x+3 / 8) /$ $(y+3 / 4)))($ Zar 1999). Statistical comparisons between the categorized behavioral responses were performed in Microsoft Office Excel 2003 using a two-sample $t$ test assuming unequal variances.

\section{Body wall contractions}

We anesthetized the leeches before and during dissections using ice-cold leech saline. The normal leech saline solution had the following composition: $115 \mathrm{mM} \mathrm{NaCl}, 4 \mathrm{mM}$ $\mathrm{KCl}, 1.8 \mathrm{mM} \mathrm{CaCl}_{2}, 1.5 \mathrm{mM} \mathrm{MgCl}, 10 \mathrm{mM}$ Glucose, $10 \mathrm{mM}$ Hepes, $\mathrm{pH}$ adjusted to 7.4 with $\mathrm{NaOH}$. Experiments were performed in leech saline at room temperature $(20$ $22^{\circ} \mathrm{C}$ ). We isolated segments 8 through 12 of the 21 leech midbody segments and removed all ganglia except the ganglion in segment 10. A blunted Sylgard-coated syringe needle was inserted through the gut and pinned the body wall of segments 8 and 12 to the Sylgard-coated syringe needle. The preparation was suspended in a specially designed dish so that the entire preparation was submerged in normal leech saline but the dorsal body wall was not in contact with the surface of the dish. We mechanically stimulated the ventral body wall adjacent to midbody ganglion 10 , halfway between the ventral midline and the lateral edge of the body wall. Because Erpobdella appeared to habituate to repeated stimulation, we measured the body wall movement from the first stimulation in both species.

The stimulus apparatus and behavioral video recording design was described previously (Thomson and Kristan 2006; Baca et al. 2008). Briefly, we used a Dual-Mode Lever Arm System (Aurora Scientific, Ontario, Canada, Model 300B) to deliver a $200 \mathrm{mN}$ tactile stimulus to the body wall with a $1 \mathrm{~mm}$ diameter bead of epoxy on the tip of a needle. The head stage of the force controller was mounted on a micromanipulator (Narishige International, East Meadow, NY). We imaged the body wall preparation using a Wild dissection microscope and a C-Mounted Hitachi KP-M1 monochrome CCD camera (Image Labs International, Bozeman, MT). We captured the images were captured at $5 \mathrm{~Hz}$ and digitized them using a Data Translation frame grabber card (DT3155) controlled with the MATLAB Image Acquisition Toolbox (The Mathworks, Natick, MA). The video and stimulus controller were synchronized using Axograph 4.9 software (Axon Instruments, Union City, CA).

Body wall motion was tracked using an optic flow algorithm (Thomson and Kristan 2006; Baca et al. 2008). We determined body wall movement for 50 frames of each video segment that spanned the response time and calculated the movement of the innervated body wall in 3-5 annuli anterior to the stimulus site for $1 \mathrm{~s}$ after stimulus application. The body wall was divided into 100 anteriorposterior lines and calculated the mean movement along each line. We averaged lines 10-40 to determine the average movement on the side of the body wall where the stimulus was applied ('on-target') and averaged lines 60-90 to determine the movement on the non-stimulated side of the body wall ('off-target'). To compare movements between animals of different sizes, we normalized measurements to the number of annuli. The movement on-target was compared to the movement off-target by performing a paired two-sample $t$ test for means in Microsoft Excel.

$\mathrm{P}$ cell response to mechanical stimulation

We tested the responses of $\mathrm{P}$ cells to body wall stimulation using a semi-intact preparation. Leeches were anesthetized and treated as described above. We isolated five segments, cut the body wall along the dorsal midline, and removed all ganglia except the middle ganglion. We cut a hole in the ventral body wall above the ganglion and pinned it in a Sylgard dish with the skin side facing up. In Erpobdella, we cut the dorsal posterior (DP) nerves so we could flatten the body wall in the Sylgard dish. We mechanically stimulated the body wall using the Dual-Mode Lever Arm System 
described above while recording intracellularly from the touch $(\mathrm{T})$, pressure $(\mathrm{P})$, and nociceptive $(\mathrm{N})$ cells in Hirudo and their putative homologs in Erpobdella.

We recorded intracellularly in bridge mode from $\mathrm{P}$ cells with $20-40 \mathrm{M} \Omega$ sharp glass microelectrodes filled with a $2 \mathrm{M}$ potassium acetate solution containing $20 \mathrm{mM} \mathrm{KCl}$ connected to an Axoclamp 2B amplifier (Axon Instruments, Union City, CA) and digitized the recordings using a National Instruments BNC-2090 (National Instruments, Austin, TX). We acquired the recordings and delivered stimulus trains using Axograph 4.9 software. We collected electrophysiology data at $5 \mathrm{kHz}$.

To inject fluorescent dyes into neurons, the electrode tips were back-filled with a $2.5 \%$ Alexafluor 568 solution then filled the electrode with $3 \mathrm{M} \mathrm{KCl}$. We injected the dye into the somata of neurons using pulses of $+3 \mathrm{nA}$ at $1 \mathrm{~Hz}$ with a $50 \%$ duty cycle. We imaged the cells using a Bio-Rad Radiance confocal microscope and captured using Bio-Rad LaserSharp2000 software (Bio-Rad Laboratories, Hercules, CA).

\section{Connections between $\mathrm{P}$ cells}

To test the connections between $\mathrm{P}$ cells, we recorded intracellularly as described above except we acquired the recordings and delivered stimulus trains using custom software written in LabVIEW 5.0 (National Instruments, Austin, TX). We stimulated one $\mathrm{P}$ cell $\left(\mathrm{P}_{\mathrm{PRE}}\right)$ with bursts of five pulses at $25 \mathrm{~Hz}$ while recording postsynaptic potentials in a second $\mathrm{P}$ cell $\left(\mathrm{P}_{\mathrm{POST}}\right)$. Each pulse was $2-3 \mathrm{nA}$ in amplitude and lasted $20 \mathrm{~ms}$; each pulse produced a single action potential in $\mathrm{P}_{\mathrm{PRE}}$. We chose to deliver a train of action potentials to examine connectivity for two reasons. First, previous studies examining connections among mechanosensory cells in Hirudo have shown complex synaptic connections between cells (Baylor and Nicholls 1969; Burgin and Szczupak 2003): a single action potential in the stimulated cell produces an excitatory postsynaptic potential (EPSP) in the postsynaptic cell; multiple presynaptic action potentials produces an EPSP in the postsynaptic cell followed by an inhibitory postsynaptic potential (IPSP). Second, previous studies of local bending have shown that body wall stimulation produces a train of action potentials in the stimulated P cell (Kristan 1982; Lewis and Kristan 1998a; Thomson and Kristan 2006). We wanted our imposed stimulus to resemble a normal response to body wall stimulation.

The magnitude of the postsynaptic potentials was measured by calculating the area of the membrane potential deviation from the baseline membrane potential in $\mathrm{P}_{\text {POST }}$ during the $500 \mathrm{~ms}$ period following the first stimulus pulse in $\mathrm{P}_{\mathrm{PRE}}$. The baseline was measured as the mean membrane voltage in the $50 \mathrm{~ms}$ prior the first stimulus pulse. To obtain a control "response" for $\mathrm{P}_{\mathrm{POST}}$, we measured the average membrane potential in a $50 \mathrm{~ms}$ "baseline" period starting $2 \mathrm{~s}$ after the last stimulus pulse in a burst. We then measured the area of deviation from the baseline in the following $500 \mathrm{~ms}$ "response" period. In Erpobdella, $\mathrm{P}_{\mathrm{POST}}$ neurons often generated action potentials in response to a $\mathrm{P}_{\mathrm{PRE}}$ spike burst. To avoid including the action potentials in our measurements of synaptic potentials we drew a line from the initiation point of the action potential to the end of the afterhyperpolarization and calculated the area of deviation under this line. These procedures were performed for all $\mathrm{P}$ to $\mathrm{P}$ connections.

To capture the features of the complex PSPs between pairs of $\mathrm{P}$ cells in Hirudo, we measured membrane potential changes in the postsynaptic $\mathrm{P}_{\mathrm{V}}$ when the other $\mathrm{P}_{\mathrm{V}}$ was stimulated. The membrane potential was measured over two time periods: (1) the $50 \mathrm{~ms}$ immediately following the first stimulus pulse, and (2) the subsequent $100 \mathrm{~ms}$. The baseline and control periods were defined as described above. We performed data analysis using MATLAB 6.1. Statistical tests were performed in Microsoft Excel.

To block polysynaptic transmission we modified the normal leech saline to create a solution with $10 \mathrm{mM} \mathrm{MgCl}_{2}$ and $10 \mathrm{mM} \mathrm{CaCl}_{2}(\mathrm{NaCl}$ was adjusted to maintain a constant osmolarity). For experiments using Erpobdella ganglia, we used a solution with $20 \mathrm{mM} \mathrm{MgCl}_{2}$ and $0 \mathrm{mM} \mathrm{CaCl}$ to block all chemical synaptic transmission (Baylor and Nicho1ls 1969). In the experiments using Hirudo ganglia, we had difficulty reversing the effects of the $20 \mathrm{mM} \mathrm{MgCl}$ and $0 \mathrm{mM} \mathrm{CaCl}$. solution, so we instead used a solution with $10 \mathrm{mM} \mathrm{MgCl}_{2}$ and $1 \mathrm{mM} \mathrm{CaCl}_{2}$ to block chemical synaptic transmission (Burgin and Szczupak 2003).

Body wall contractions caused by $\mathrm{P}$ cell stimulation

We made an isolated body wall preparation with a single exposed ganglion as described above. In Erpobdella, we cut the DP nerves so we could flatten the body wall in the Sylgard dish. We imaged body wall movements while delivering bursts of five pulses into a P cell at $25 \mathrm{~Hz}$. We determined longitudinal and lateral body wall movement for 50 frames of each video segment that spanned the response time. For longitudinal movement, we calculated body wall movement in the anterior three annuli of the innervated segment for $1 \mathrm{~s}$ after stimulus application. For lateral movement, we calculated body wall movement in the middle three annuli of the innervated segment for $1 \mathrm{~s}$ after stimulus application. We divided the body wall into four regions and calculated the average movement in each region. The right and left dorsal regions each spanned from the dorsal midline to the respective lateral edge. The right and left ventral regions each spanned from the respective lateral edge to the edge of the hole in the body wall. 
To compare movements between animals of different sizes, we normalized measurements to the number of annuli. For lateral movement, we defined positive motion as movement toward the midline: when a $\mathrm{P}_{\mathrm{D}}$ cell was stimulated, movement toward the dorsal midline was positive motion, and when a $\mathrm{P}_{\mathrm{V}}$ cell was stimulated, movement toward the ventral midline was positive motion. The average movements of the four regions were compared with a single-factor ANOVA in Microsoft Excel. If the ANOVA was significant at the 0.05-level, we compared individual regions by performing paired two-sample $t$ tests for means in Microsoft Excel.

\section{Results}

\section{Intact leech behavior}

We stimulated intact Hirudo and Erpobdella with localized electrical pulses on the dorsal and ventral surfaces of midbody segments and scored their behavioral responses. We divided the responses into six categories: tensing, local bending, whole-body bending, crawling, swimming, and shortening (see "Methods"). Hirudo $(n=14)$ showed only three of the behavioral responses: swimming, whole-body bending, and local bending, with whole-body bending being the most common response (Fig. 1). Each of these behaviors has been previously observed in Hirudo in response to a light shock applied at the anterior or posterior

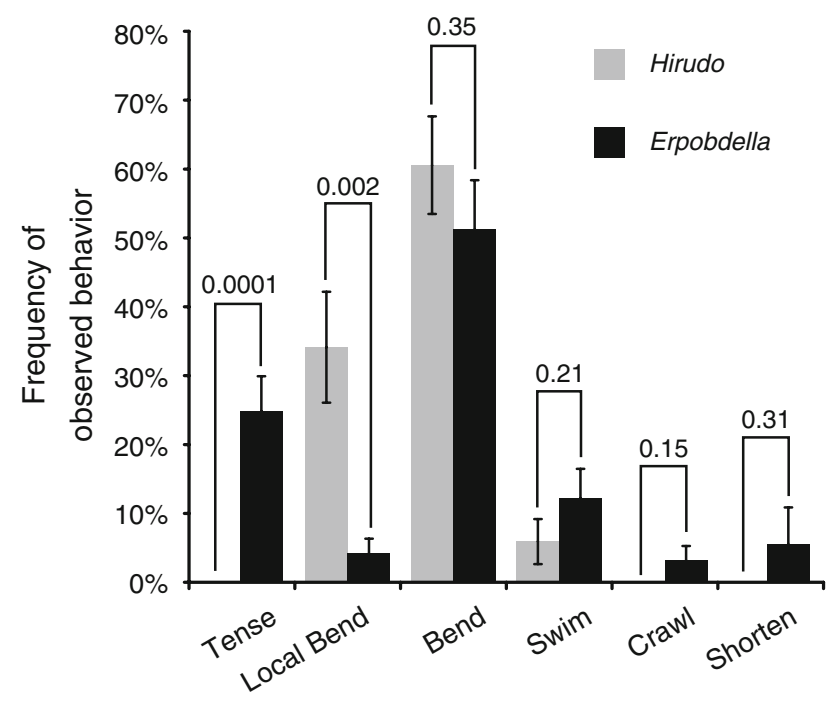

Fig. 1 Behavioral responses to trains of weak electrical shocks that mimic light-to-moderate levels of touch in Hirudo verbana and Erpobdella obscura. Hirudo data are in light gray, Erpobdella are in dark gray. The error bars indicate SEM. The number above each pair of bars is the $P$ value from the $t$ test performed on the transformed data (see "Methods"). For Hirudo, $n=14$; for Erpobdella, $n=15$ ends (Kristan et al. 1982; Misell et al. 1998). Erpobdella $(n=15)$ showed all six behavioral responses.

To test the null hypotheses that there was no difference in the responses observed in the two species, we performed a two-sample $t$ test assuming unequal variances for the frequency of each behavioral response. We rejected the hypothesis for similarity for both tensing [(mean \pm SEM) Hirudo $=0 \pm 0 \% ;$ Erpobdella $=25 \pm 5 \% ; P=0.0001]$ and local bending (Hirudo $=34 \pm 8 \%$; Erpobdella $=4 \pm 2 \%$; $P=0.002)$, but cannot reject the null hypothesis for wholebody bending $(P=0.35)$, swimming $(P=0.21)$, crawling $(P=0.15)$, or shortening $(P=0.31)$. Hence, the two species differ in their probability of responding by tensing and local bending, but are similar in their probability of producing the four other behaviors.

\section{Body wall movement}

To measure local bending and tensing more accurately, we used a body wall preparation consisting of five body segments, with only the middle segment innervated by its ganglion (Fig. 2a). When touched on the right side of the ventral body wall, Hirudo contracted asymmetrically: the right side shortened more strongly than the left side (Fig. 2b). Because of the large variability between preparations, we normalized the data for each preparation to its maximum contraction strength. In Hirudo, the stimulated side shortened significantly more than did the opposite side [stimulated $($ mean $\pm \mathrm{SEM})=63.0 \pm 6.8 \%$; contralateral $=$ $34.1 \pm 8.7 \% ; P=0.04 ; n=5)]$. This difference constitutes the local bending response (Lewis and Kristan 1998a; Baca et al. 2005, 2008). In contrast, Erpobdella showed a nearly equal contraction on the ipsilateral and contralateral sides ( stimulated $=64.9 \pm 6.5 \% ; \quad$ contralateral $=54.4 \pm 7.7 \%$; $P=0.36 ; n=5)$; this similarity constitutes the 'tensing' response.

\section{Identification of $\mathrm{P}$ cells}

To begin a comparative study of the neuronal basis for local bending and tensing, we recorded from the pressure mechanosensory neurons ( $\mathrm{P}$ cells). The $\mathrm{P}$ cells are responsible for producing local bending in Hirudo (Kristan 1982; Lockery and Kristan 1990a; Lewis and Kristan 1998a). The $\mathrm{P}$ cells of Hirudo have been well-studied and are easily identifiable based on their size, location, and electrical properties (Nicholls and Baylor 1968). To determine whether the P cells in Erpobdella were similar to those in Hirudo, we performed similar electrophysiological and anatomical studies on ganglia from each species.

In Hirudo, the $\mathrm{P}$ cells that innervate the ventral body wall $\left(\mathrm{P}_{\mathrm{V}}\right.$ cells) are located between the roots of the lateral nerves and their somata are about $50 \mu \mathrm{m}$ in diameter; a 
(a)

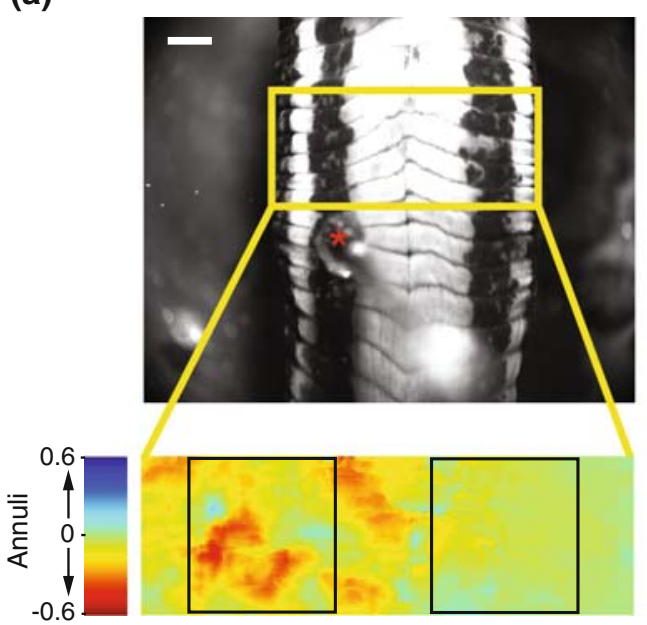

(b)

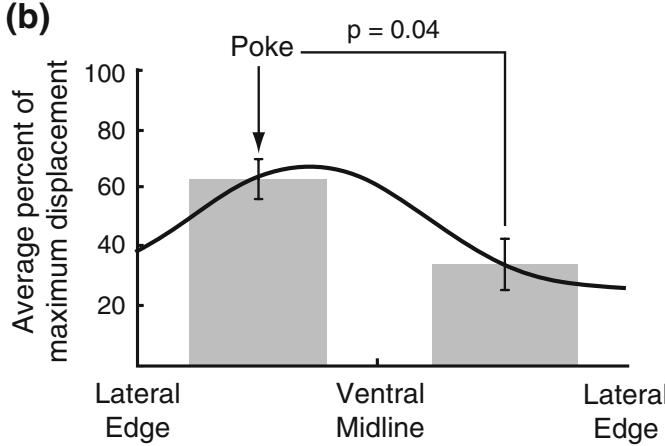

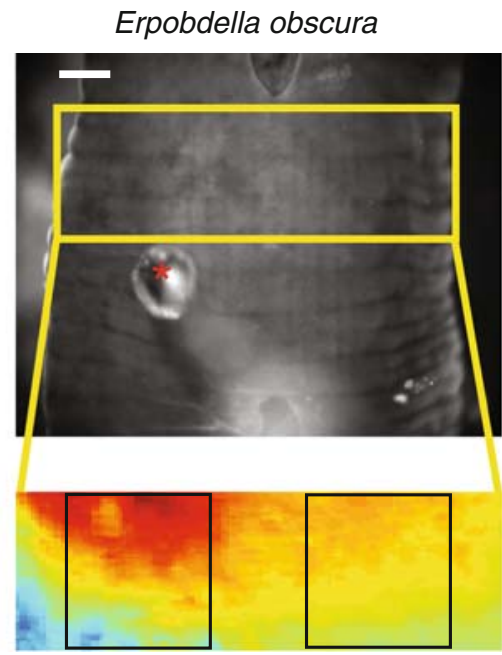

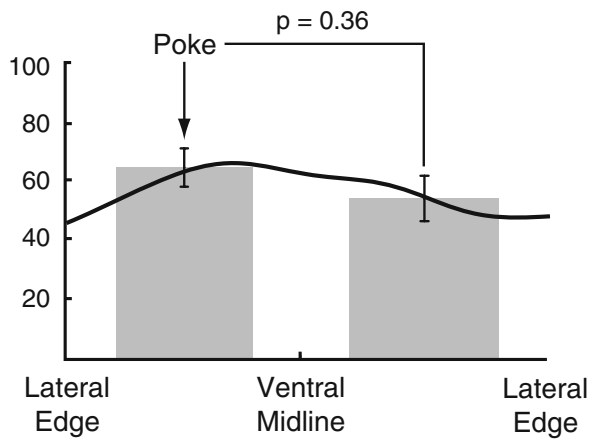

Fig. 2 Responses to skin stimulation in Hirudo and Erpobdella. We pinned five segments of body wall onto a Sylgard-coated syringe in a saline-filled chamber, ventral side up, with only the middle segment innervated by a ganglion. The circumferential lines mark annuli; a segment consists of five annuli. Scale bars $1 \mathrm{~mm}$. a Top panels are video frames of Hirudo (left) and Erpobdella (right) before stimulation. The red asterisks mark the stimulus probe. The yellow box over the picture of the leech outlines the area of the body wall that was analyzed for motion. Bottom panels are motion analysis of the body wall after stimulation. The expanded colored rectangle indicates movements of the region between 0 and $1 \mathrm{~s}$; cool colors (blue) indicate movement

similar neuron was found in Erpobdella (Fig. 3a). The $\mathrm{P}_{\mathrm{V}}$ cells in Hirudo and their putative homologs in Erpobdella all sent neurites through both of the ipsilateral nerve roots as well as into both the anterior and posterior connectives. In Hirudo, the P cells that innervate the dorsal body wall $\left(\mathrm{P}_{\mathrm{D}}\right.$ cells) are located in the posterior, medial packet of cells. Each $P_{D}$ cell sent a neurite out the posterior nerve root, and sent neurites into both the anterior and posterior connectives; similar neurons were found in Erpobdella (Fig. 3b). The only consistent difference in the two species was that Hirudo P cells typically had 1-3 secondary processes that extend contralaterally, whereas the putative $\mathrm{P}$ cells in Erpobdella had no such contralateral processes.

After the initial electrode penetration, the P cells did not show spontaneous activity in either species. Injecting a upward and warm colors (yellow-red) indicate movements downward. The black boxes on the expanded rectangle outline the contralateral and ipsilateral areas used to measure body wall movements. b Average magnitude of body wall movements of the black boxed area in Hirudo (left; $n=5$ ) and Erpobdella (right; $n=5$ ). The area analyzed was divided into 100 vertical columns. The black line is the smoothed mean percentage of maximum displacement for each of the 100 columns. The gray rectangles are the mean percentage of maximum displacement over the areas contained in the black boxes in $\mathbf{a}$. The error bars indicate SEM

small depolarizing current generated a single action potential in both species (Fig. 3c). Injecting a hyperpolarizing current showed a "sag" response in P cells in both species (Fig. 3d), which was often followed by an action potential upon release of the hyperpolarizing current.

In addition to P cells, Hirudo has touch (T) and nociceptive $(\mathrm{N})$ mechanosensory neurons that could possibly be mistaken for $\mathrm{P}$ cells. We therefore recorded intracellularly from T, P, and N cells in Hirudo as well as from their putative homologs in Erpobdella while stimulating the body wall with $100 \mathrm{mN} / \mathrm{mm}^{2}$ of force. T cells in both species showed a rapid burst of action potentials when the stimulus was applied and a few action potentials when the stimulus was removed (Fig. 4a), similar to the responses described previously in Hirudo (Lewis and Kristan 1998b; Nicholls 
Fig. 3 Comparison of P cells in Hirudo to the putative $\mathrm{P}$ cell homologs in Erpobdella. a Dye fills of a $\mathrm{P}_{\mathrm{V}}$ cell in Hirudo (left) and a putative $\mathrm{P}_{\mathrm{V}}$ homolog in $\mathrm{Er}$ pobdella (right). Scale bars represent $100 \mu \mathrm{m}$. These are typical morphologies of two $\mathrm{P}_{\mathrm{V}}$ cells in Hirudo and five putative $\mathrm{P}_{\mathrm{V}}$ homologs in Erpobdella. b Dye fills of a $\mathrm{P}_{\mathrm{D}}$ cell in Hirudo (left) and a putative $\mathrm{P}_{\mathrm{D}}$ homolog in $\mathrm{Er}$ pobdella (right). These are typical morphologies of two $P_{D}$ cells in Hirudo and three putative $\mathrm{P}_{\mathrm{D}}$ homologs in Erpobdella. Scale bars represent $100 \mu \mathrm{m}$. a, b Brightness and contrast were adjusted in Adobe Photoshop. c Representative traces showing the responses of a Hirudo P cell (left) and a putative Erpobdella $\mathrm{P}$ cell homolog (right) to a depolarizing current. Top traces are current clamp recordings from the $\mathrm{P}$ cells and the bottom traces show the magnitude and timing of depolarizing current. d Representative traces showing a sag current in a Hirudo P cell (left) and a putative Erpobdella $\mathrm{P}$ cell homolog (right) triggered by a prolonged hyperpolarization. Top traces are current clamp recordings from the $\mathrm{P}$ cells and the bottom traces show the magnitude and timing of hyperpolarizing current (a)

Hirudo verbana

(b)

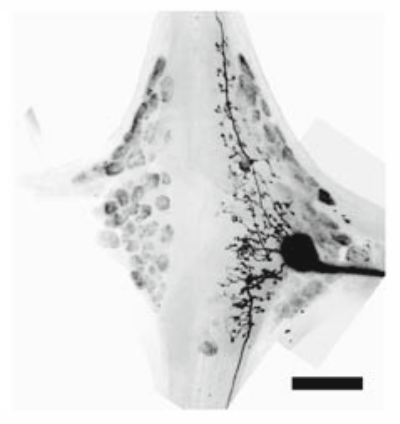

(c)

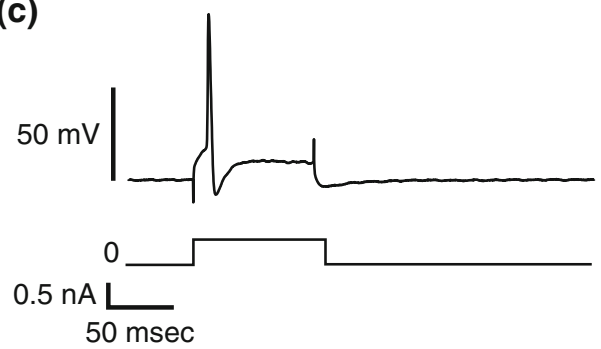

(d)

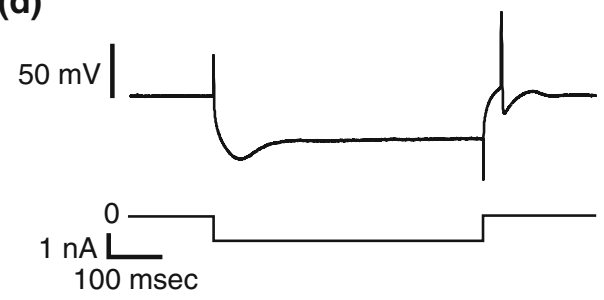

\section{Erpobdella obscura}
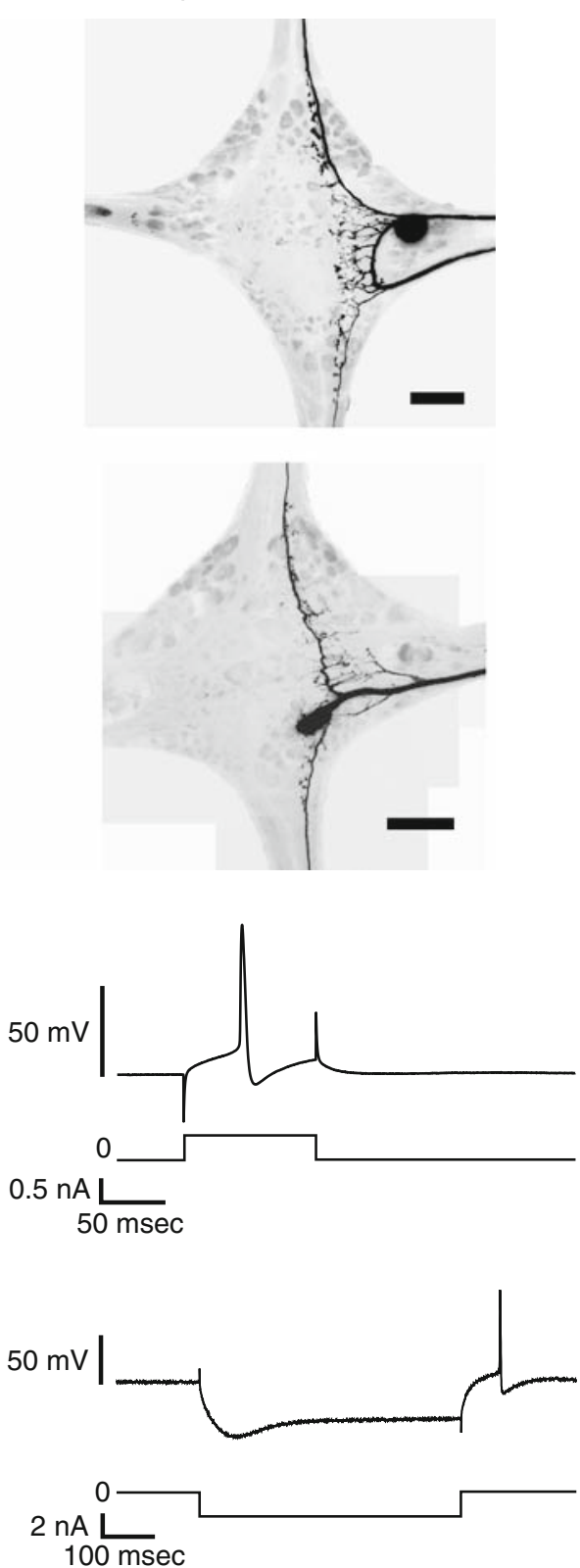

and Baylor 1968). During the first $100 \mathrm{~ms}$ of stimulus application, Hirudo T cells fired an average of $6.3 \pm 0.8$ (mean $\pm \mathrm{SEM} ; n=4$ ) action potentials while the putative Erpobdella $\mathrm{T}$ cells fired $5.8 \pm 0.8$ action potentials $(n=4)$.

The P cells in Hirudo and the putative P cells in Erpobdella showed a tonic response to body wall stimulation (Fig. 4b), qualitatively similar to the responses observed previously in Hirudo (Lewis and Kristan 1998b; Thomson and Kristan 2006). During the $500 \mathrm{~ms}$ of stimulation, the P cell in Erpobdella fired a significantly greater number of action potentials than did the $\mathrm{P}$ cell in Hirudo $[$ Erpobdella $=9.3 \pm 1.4 \quad(n=8) ; \quad$ Hirudo $=5.5 \pm 0.6$ $(n=10) ; t$ test: $P=0.034]$.
The $\mathrm{N}$ cells in both species showed a tonic response to body wall stimulation (Fig. 4c), qualitatively similar to the responses observed previously in Hirudo (Nicholls and Baylor 1968; Johansen and Kleinhaus 1986). During the $500 \mathrm{~ms}$ of stimulation, the $\mathrm{N}$ cell in Hirudo fired an average of $2.2 \pm 0.6(n=4)$ action potentials while the $\mathrm{N}$ cell in Erpobdella fired an average of $3.5 \pm 0.9$ action potentials $(n=4)$.

We also occasionally recorded from a cell near the putative $\mathrm{P}_{\mathrm{V}}$-homolog in Erpobdella that was similar in size, location and physiological properties to the Leydig cells in Hirudo (Keyser et al. 1982). Moreover, the only other large neurons near the putative $\mathrm{P}_{\mathrm{D}}$-homolog in Erpobdella were similar in location and physiology to the $\mathrm{AE}$ and 251 neu- 
Fig. 4 Responses of T, P and N cells to mechanical stimulation of the body wall in Hirudo and Erpobdella. a Representative traces showing the response of a $\mathrm{T}$ cell in Hirudo (left) and Erpobdella (right) to a $500 \mathrm{~ms}$ stimulation of the body wall with a force of $100 \mathrm{mN} / \mathrm{mm}^{2}$. The black bar represents when the mechanical stimulus was applied. b Representative traces showing the response of a $\mathrm{P}$ cell in Hirudo (left) and Erpobdella (right) to a stimulation of the body wall with a force of $100 \mathrm{mN} / \mathrm{mm}^{2}$. c Representative traces showing the response of an $\mathrm{N}$ cell in Hirudo (left) and Erpobdella (right) to a stimulation of the body wall with a force of $100 \mathrm{mN} / \mathrm{mm}^{2}$ (a) T cells

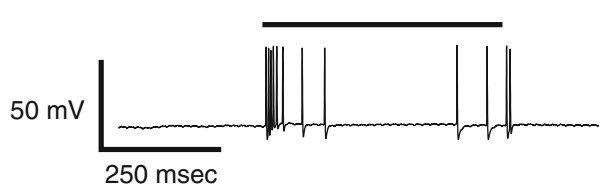

(b) $P$ cells

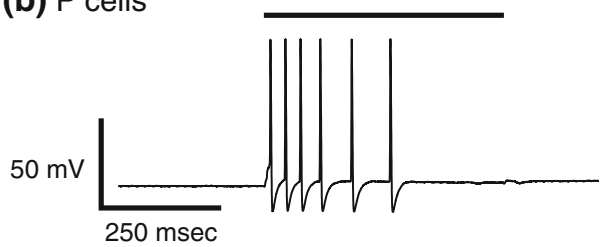

(c) $\mathrm{N}$ cells

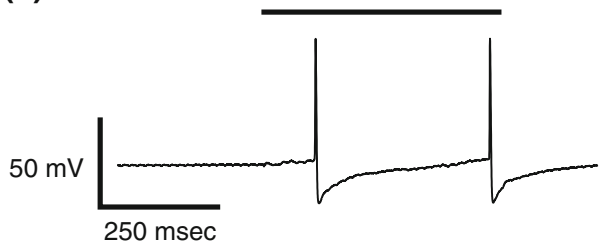

Erpobdella obscura
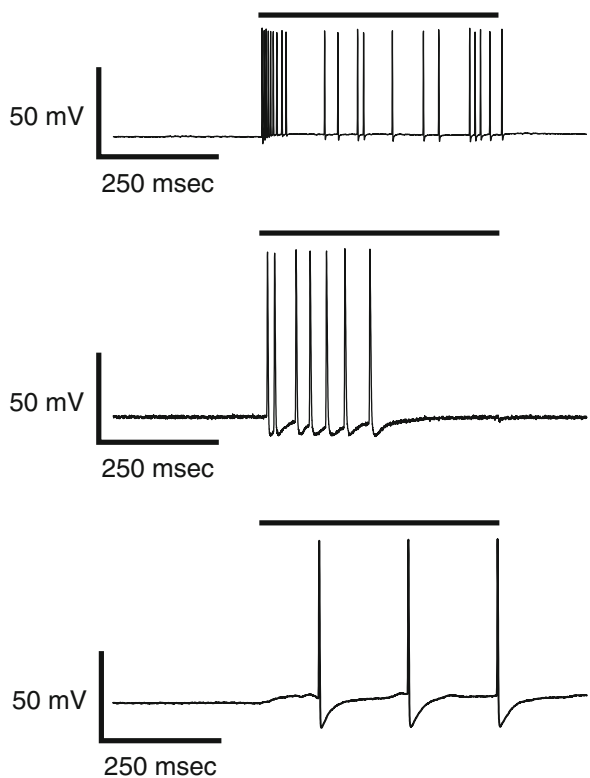

rons in Hirudo (Rodriguez et al. 2004). Therefore, based on the similarity in location, morphology, physiology, and response to mechanical stimulation, we conclude that the putative T, P, and N cells in Erpobdella are homologs of the T, $\mathrm{P}$ and $\mathrm{N}$ cells in Hirudo.

\section{Connections between $\mathrm{P}$ cells}

We first investigated the connections between the $\mathrm{P}_{\mathrm{V}}$ cells in the segmental ganglia in Hirudo and Erpobdella. In Hir$u d o$, when one $\mathrm{P}_{\mathrm{V}}$ was stimulated to produce five action potentials, the postsynaptic response contained a mixture of excitation and inhibition (Fig. 5a). When one $\mathrm{P}_{\mathrm{V}}$ was stimulated, the other $\mathrm{P}_{\mathrm{V}}$ was depolarized during the first $50 \mathrm{~ms}$ by a mean $\pm \mathrm{SEM}$ of $0.09 \pm 0.04 \mathrm{mV}$ (control $=$ $-0.02 \pm 0.03 \mathrm{mV} ; n=13$; paired $t$ test: $P=0.02$ ) and was hyperpolarized over the next $100 \mathrm{~ms}$ by a mean of $-0.54 \pm 0.12 \mathrm{mV} \quad$ (control $=-0.01 \pm 0.03 \mathrm{mV} ; \quad n=13$; paired $t$ test: $P=0.0005$ ) (Fig. 5b). In Erpobdella, the five action potentials in one $\mathrm{P}_{\mathrm{V}}$ produced a strong depolarization in the other $\mathrm{P}_{\mathrm{V}}$ (mean area of deviation $\pm \mathrm{SEM}=$ $802.2 \pm 249.5 \mathrm{mV} \mathrm{ms}$ ) that was significantly different from control values (control $=-19.8 \pm 28.0 \mathrm{mV} \mathrm{ms;} n=7$; paired $t$ test: $P=0.02$ ) (Fig. $5 \mathrm{a}, \mathrm{c}$ ). In three of the seven preparations, the stimulus caused the contralateral $\mathrm{P}_{\mathrm{V}}$ to fire at least one action potential.

We tested all other combinations of connections between $\mathrm{P}$ cells in both Hirudo and Erpobdella and found similar results (Fig. 6). In Hirudo, five action potentials in one $\mathrm{P}$ cell caused a net hyperpolarization in the other P cells; in Erpobdella, five action potentials in one $\mathrm{P}$ cell caused a strong depolarization in the other $\mathrm{P}$ cells. For Hirudo, the mean deviation from baseline for none of the pairs tested were significantly different from any of the other pairs (ANOVA: $F_{5,37}=0.398, P=0.847$ ). The mean deviation from baseline for all pairs of $\mathrm{P}$ cells was $-61.1 \pm$ $8.2 \mathrm{mV} \mathrm{ms}$ ( $\pm \mathrm{SEM}$; control $=-4.8 \pm 11.9 \mathrm{mV} \mathrm{ms} ; n=6$; paired $t$ test: $P=0.006)$. For Erpobdella, too, none of the pairs tested were statistically different from any of the other pairs (ANOVA: $F_{5,29}=0.345, P=0.881$ ). The mean deviation for all pairs of $\mathrm{P}$ cells was $906.0 \pm 74.0 \mathrm{mV} \mathrm{ms}$ (control $=4.2 \pm 10.2 \mathrm{mV} \mathrm{ms;} n=6$; paired $t$ test: $P=$ 0.0001). Each pair of P cells tested in Hirudo was significantly different from its complimentary pair in Erpobdella ( $t$ test: $\mathrm{P}_{\mathrm{V}}$ to $\mathrm{P}_{\mathrm{V}}: P=0.015 ; \mathrm{P}_{\mathrm{V}}$ to $\mathrm{iP}_{\mathrm{D}}: P=0.050 ; \mathrm{P}_{\mathrm{V}}$ to $c \mathrm{P}_{\mathrm{D}}$ : $P=0.030 ; \mathrm{P}_{\mathrm{D}}$ to $\mathrm{iP}_{\mathrm{V}}: P=0.048 ; \mathrm{P}_{\mathrm{D}}$ to $\mathrm{cP}_{\mathrm{V}}: P=0.032 ; \mathrm{P}_{\mathrm{D}}$ to $\left.\mathrm{P}_{\mathrm{D}}: P=0.008\right)$. The mean deviation for all pairs of $\mathrm{P}$ cells in Hirudo was also significantly different from the mean deviation for all pairs of P cells in Erpobdella $(P<0.0001)$. In 25 of the 35 Erpobdella preparations, the stimulation of one $\mathrm{P}$ cell caused the other $\mathrm{P}$ cell to fire at least one action potential.

Next we determined whether the connection between $\mathrm{P}$ cells in Hirudo was monosynaptic, polysynaptic or electrical. When we bathed a ganglion in a high $\mathrm{Mg}^{2+} /$ high $\mathrm{Ca}^{2+}$ solution, the IPSPs between $\mathrm{P}$ cells were eliminated and a small depolarization was observed (mean $\pm \mathrm{SEM}=$ $1.8 \pm 0.3 \mathrm{mV} ; n=3$ ), indicating that the inhibition was due to a polysynaptic chemical connection between $\mathrm{P}$ cells (Fig. 7a). When bathed in a high $\mathrm{Mg}^{2+} /$ low $\mathrm{Ca}^{2+}$ solution, the depolarization still persisted $(0.8 \pm 0.2 \mathrm{mV} ; n=3)$, indicating that part of the depolarization resulted from an 


\section{(a)}

Hirudo verbana

$\mathrm{cP}_{\mathrm{V}}$
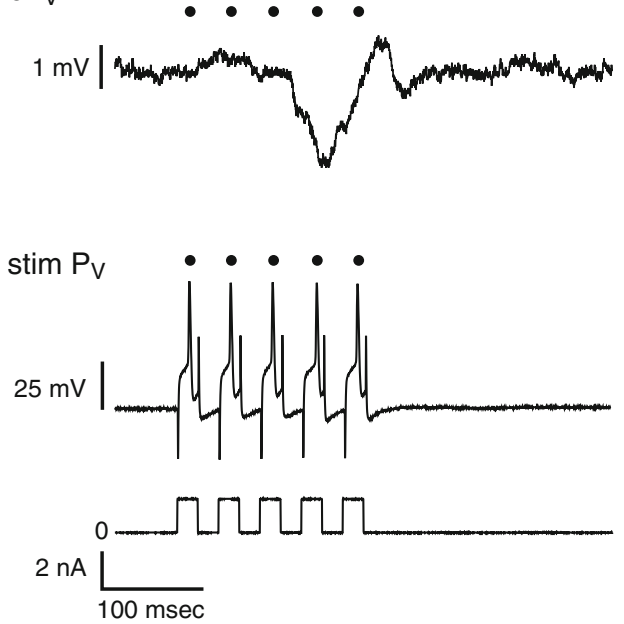

(b)
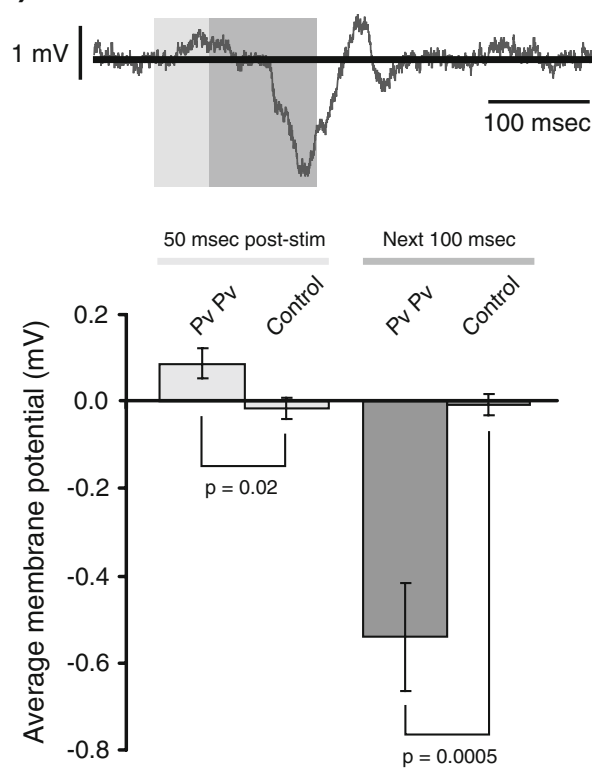

Fig. $5 \mathrm{P}_{\mathrm{V}}$ to $\mathrm{P}_{\mathrm{V}}$ connections in Hirudo and Erpobdella. a Representative response of a ventral $\mathrm{P}$ cell $\left(P_{V}\right)$ to stimulation of the other $\mathrm{P}_{\mathrm{V}}$ in a Hirudo (left) and Erpobdella (right) midbody ganglion. The bottom trace shows the stimulus protocol, the middle trace shows the action potentials produced in the stimulated $\mathrm{P}_{\mathrm{V}}\left(\operatorname{stim} P_{V}\right)$ by the depolarizing pulses, and the top trace shows the response of the contralateral, nonstimulated $\mathrm{P}_{\mathrm{V}}\left(c P_{V}\right)$. In this trace, as well as in all other panels, black dots show the times of the peaks of the action potentials in the stimulated P cell. In Erpobdella, the tops of the action potentials were cropped in the top trace. The inset shows the complete response of the non-stimulated $\mathrm{P}_{\mathrm{V}}$ cell at a reduced amplification and a compressed time scale. Capacitance artifacts in the middle trace of Hirudo were partially deleted using Adobe Illustrator. b Average change in membrane potential relative to baseline in the non-stimulated $\mathrm{P}_{\mathrm{V}}$ in Hirudo. The trace is the same as the top trace in $\mathbf{a}$. The solid black line indicates the mean baseline membrane potential. The light gray box is the first $50 \mathrm{~ms}$ of stimulation. The dark gray box is the next $100 \mathrm{~ms}$. The bar
Erpobdella obscura

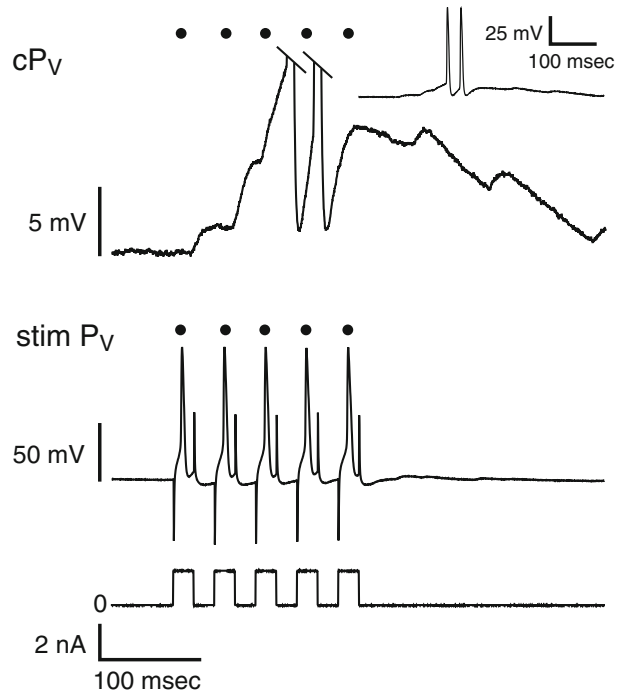

(c)
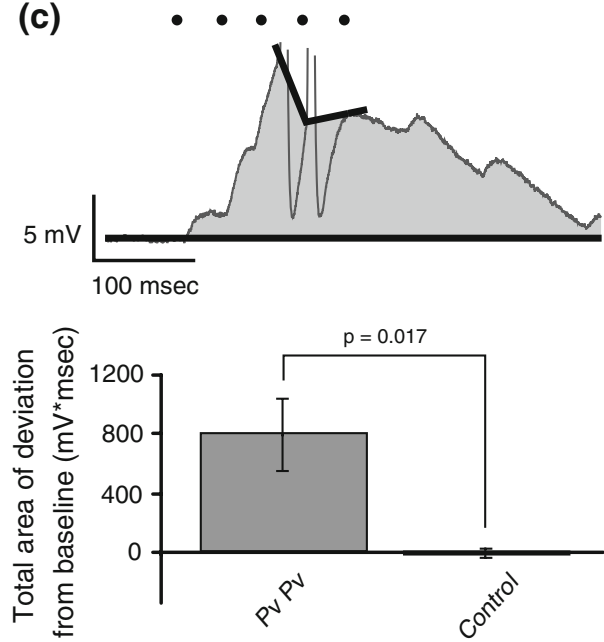

graph shows the mean change in membrane potential from baseline over the first $50 \mathrm{~ms}$ after stimulation and over the subsequent $100 \mathrm{~ms}$. The control bars are the mean change in membrane potential in the non-stimulated $\mathrm{P}_{\mathrm{V}}$ over $50 \mathrm{~ms}$ and the next $100 \mathrm{~ms}$ beginning $2 \mathrm{~s}$ after the end of the stimulus bursts. The error bars indicate SEM; $n=13$. c Quantification of the depolarization observed in the non-stimulated $\mathrm{P}_{\mathrm{V}}$ in Erpobdella. The trace is the same as the top trace in $\mathbf{a}$. The mean prestimulus membrane potential is represented by the black line. The area of the deviation from the baseline membrane potential is shaded in gray. The bar graph shows the mean shaded area in the non-stimulated $\mathrm{P}_{\mathrm{V}}$ in the $500 \mathrm{~ms}$ following the first current pulse in the stimulated cell. The action potentials were not included in our calculation of deviation from baseline (see "Methods"). The control bar is the mean shaded area in the non-stimulated $\mathrm{P}_{\mathrm{V}}$ over $500 \mathrm{~ms}$ beginning $2 \mathrm{~s}$ after the end of the stimulus bursts. The error bars indicate SEM; $n=7$. $P_{V}$ ventral $\mathrm{P}$ cell, stim stimulated, $c$ contralateral 
Fig. $6 \mathrm{P}$ to $\mathrm{P}$ connections in Hirudo and Erpobdella midbody ganglia. a Representative traces of the response of a postsynaptic $P$ cell to the stimulation of another P cell in Hirudo (left) and Erpobdella (right). Black dots in both $\mathbf{a}$ and $\mathbf{b}$ represent the peak of the action potentials in the stimulated P cell. The label subscripts ( $D$ dorsal, $V$ ventral) indicate which kind of $P$ cell was stimulated and recorded. The small letters before the recipient $\mathrm{P}$ cell indicate whether that $\mathrm{P}$ cell was ipsilateral $(i)$ or contralateral $(c)$ to the stimulated $\mathrm{P}$ cell. Taken together with the $\mathrm{P}_{\mathrm{V}}$ to $\mathrm{P}_{\mathrm{V}}$ recordings shown in Fig. 4 , these recordings represent all possible combinations of the four $P$ cells taken two at a time. b Deviation from baseline of the postsynaptic $\mathrm{P}$ cell for all $\mathrm{P}$ cell pairs in Hirudo (left) and Erpobdella (right). 'All' is the mean area of deviation from baseline for all six pairs of $\mathrm{P}$ to $\mathrm{P}$ interactions. 'Control' is the mean area of deviation from baseline for the control periods for all six pairs of $\mathrm{P}$ to $\mathrm{P}$ interactions. The error bars indicate SEM. Within a species, none of the means for the $\mathrm{P}$ to $\mathrm{P}$ interactions are significantly different from one another (Hirudo:

$P=0.847 ;$ Erpobdella:

$P=0.881$ ). Each mean for the $P$ to $\mathrm{P}$ interactions in Erpobdella is significantly different from its complementary mean in Hirudo (see "Results"). $i$ ipsilateral, $c$ contralateral, $P_{V}$ ventral P cell, $P_{D}$ dorsal P cell (a)

Hirudo verbana

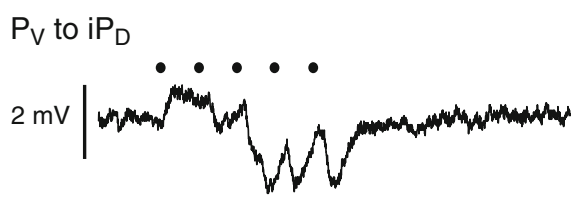

$\mathrm{P}_{\vee}$ to $\mathrm{CP}$

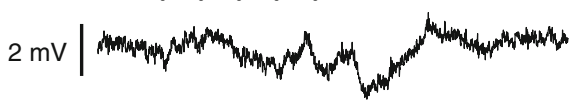

$\mathrm{P}_{\mathrm{D}}$ to $\mathrm{iP}_{\mathrm{V}}$

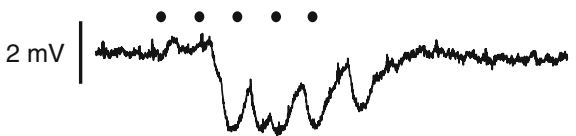

$\mathrm{P}_{\mathrm{D}}$ to $\mathrm{CPV}$...

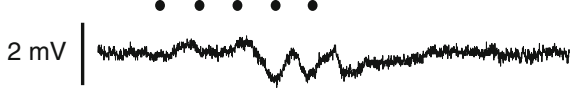

$P_{D}$ to $P_{D}$

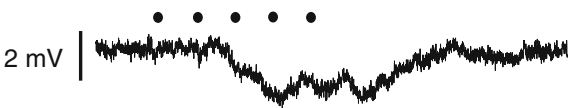

$100 \mathrm{msec}$

(b)

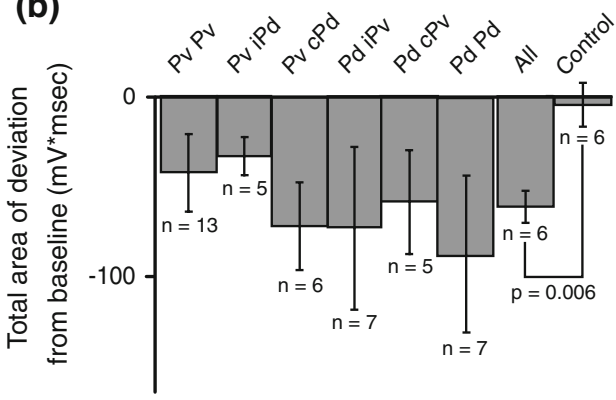

Erpobdella obscura

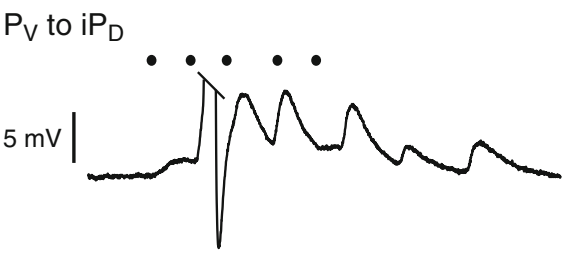

$\mathrm{P}_{\vee}$ to $\mathrm{CP}_{\mathrm{D}}$...

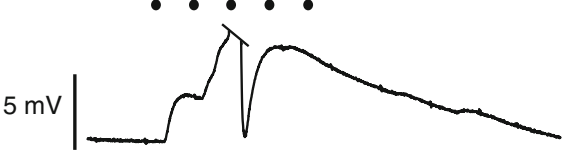

$\mathrm{P}_{\mathrm{D}}$ to $\mathrm{iP}_{\mathrm{V}}$

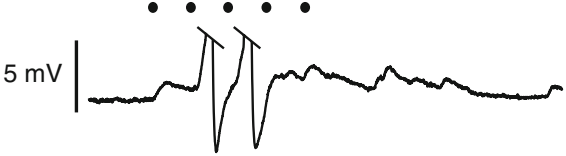

$\mathrm{P}_{\mathrm{D}}$ to $\mathrm{CPV}$

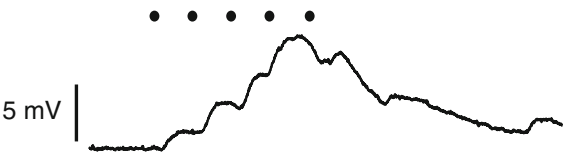

$P_{D}$ to $P_{D}$

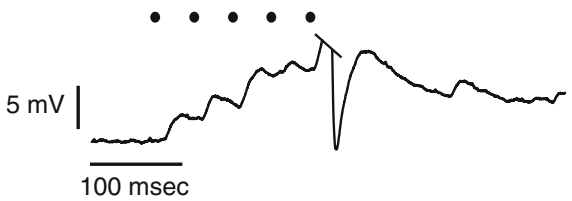

$1 \overline{00 \mathrm{msec}}$

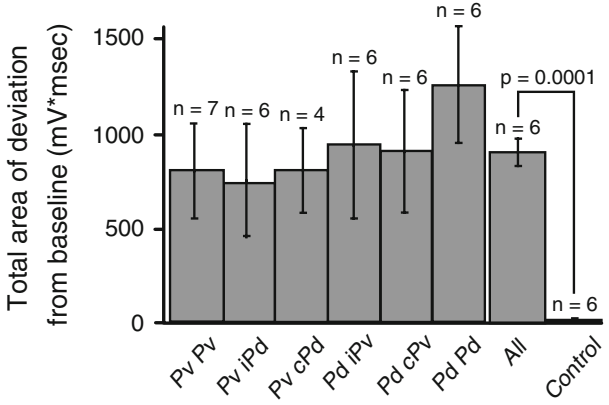

electrical connection. Passing moderate hyperpolarizing currents (1-3 nA) into one $\mathrm{P}$ cell never elicited a hyperpolarization in the other $\mathrm{P}$ cell $(n=6)$. These results suggest that the connections among P cells in Hirudo include polysynaptic chemical inhibition, monosynaptic chemical excitation, and an electrical connection.

We performed similar tests on Erpobdella P cells. When we bathed Erpobdella ganglia in a high $\mathrm{Mg}^{2+} /$ high $\mathrm{Ca}^{2+}$ solution, the EPSPs were greatly reduced, but not eliminated (mean $\pm \mathrm{SEM}=0.8 \pm 0.2 \mathrm{mV} ; n=3$ ), indicating that a major part of the excitation was due to polysynaptic chemical connections (Fig. 7b). When the ganglia were exposed to a high $\mathrm{Mg}^{2+} / 0 \mathrm{Ca}^{2+}$ solution, a small depolarizing response remained $(0.7 \pm 0.2 \mathrm{mV} ; n=3)$. When we passed hyperpolarizing currents (1-3 nA) into one $\mathrm{P}$ cell, the other P cell did not show a hyperpolarization $(n=4)$. These results suggest that the connections among P cells in Erpobdella include a polysynaptic chemical excitation and an electrical connection.

Body wall contractions caused by $\mathrm{P}$ cell stimulation

To test whether the stimulation of an individual P cell could account for the behavioral differences in Hirudo and Erpobdella, we used a body wall preparation consisting of five body segments cut along the dorsal midline. We removed all ganglia except the one in the middle segment. We cut a hole in the dorsal body wall so we could stimulate 
(a) Hirudo verbana
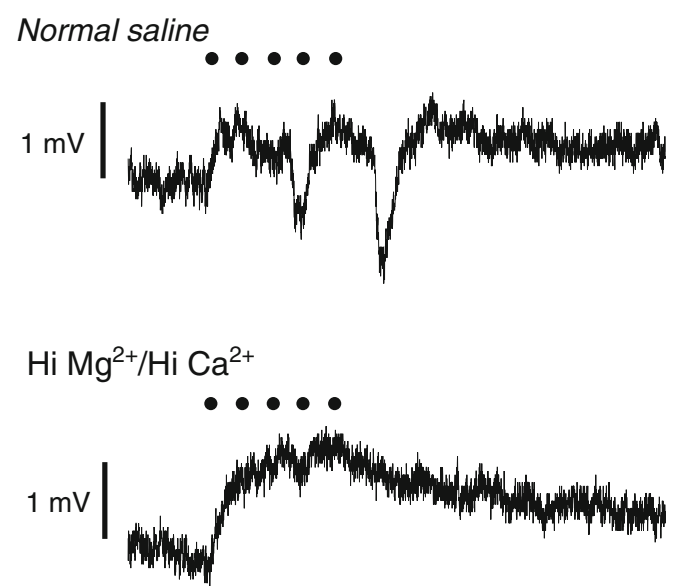

$\mathrm{Hi} \mathrm{Mg}{ }^{2+} / \mathrm{Lo} \mathrm{Ca}^{2+}$
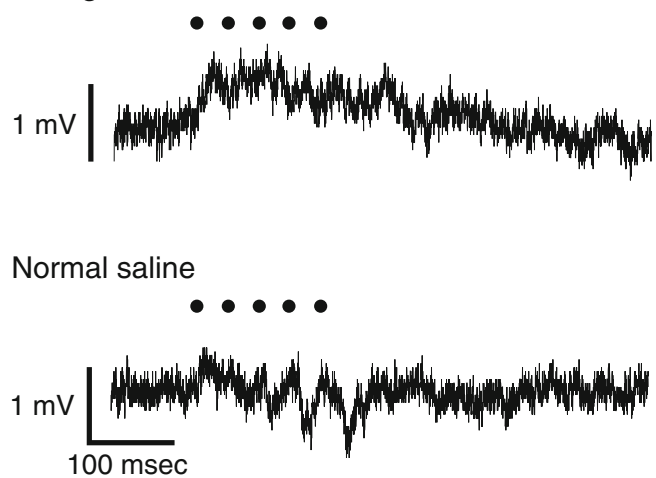

(b) Erpobdella obscura

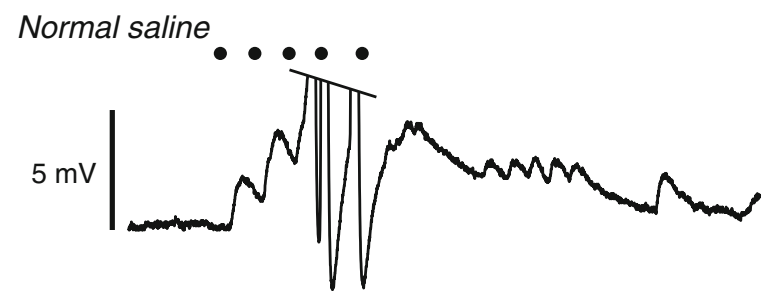

$\mathrm{Hi} \mathrm{Mg}{ }^{2+} / \mathrm{Hi} \mathrm{Ca}^{2+}$
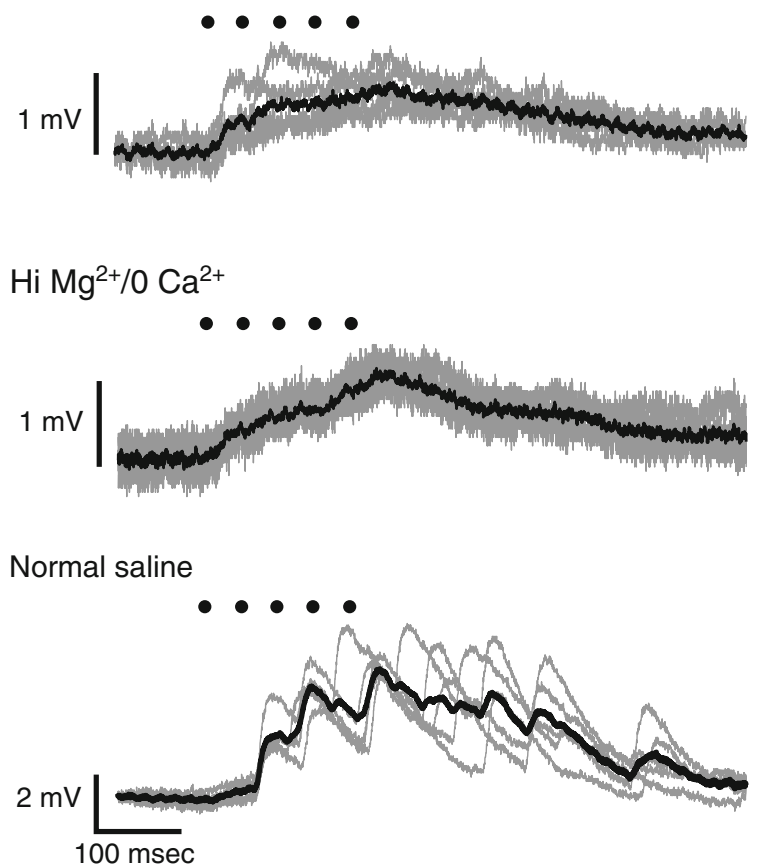

lating the contralateral $\mathrm{P}_{\mathrm{V}}$. The top trace is in normal leech saline. The next trace is in a $10 \mathrm{mM} \mathrm{Mg} \mathrm{Mg}^{2+} / 10 \mathrm{mM} \mathrm{Ca}^{2+}$ saline. The third trace is in a $20 \mathrm{mM} \mathrm{Mg}^{2+} / 0 \mathrm{mM} \mathrm{Ca}^{2+}$ saline. The bottom trace is a washout in normal saline. For the bottom three traces, five sweeps of raw data were overlapped (gray lines) along with their average (black line). $P_{V}$ ventral $\mathrm{P}$ cell, $P_{D}$ dorsal $\mathrm{P}$ cell

largest lateral movement and was significantly different from all other regions (Fig. 8c). In contrast, Erpobdella did not have significantly different longitudinal or lateral contraction between any regions (Table 1).

Because the DP nerve in Erpobdella was cut, the contraction of the dorsal body wall may have been affected. When we stimulated a $\mathrm{P}_{\mathrm{V}}$ cell, the average movement of the ipsilateral ventral body wall was $0.004 \pm 0.002$ annuli (mean $\pm \mathrm{SEM} ; n=6$ ). When we stimulated a $\mathrm{P}_{\mathrm{D}}$ cell, the average movement of the ipsilateral dorsal body wall was $0.013 \pm 0.016$ annuli $(n=4)$. The movement of the body wall was not significantly different $(t$ test: $P=0.60$ ). These results indicate that there was longitudinal muscle contraction of the dorsal body wall even though the DP nerve was cut. 
(a)
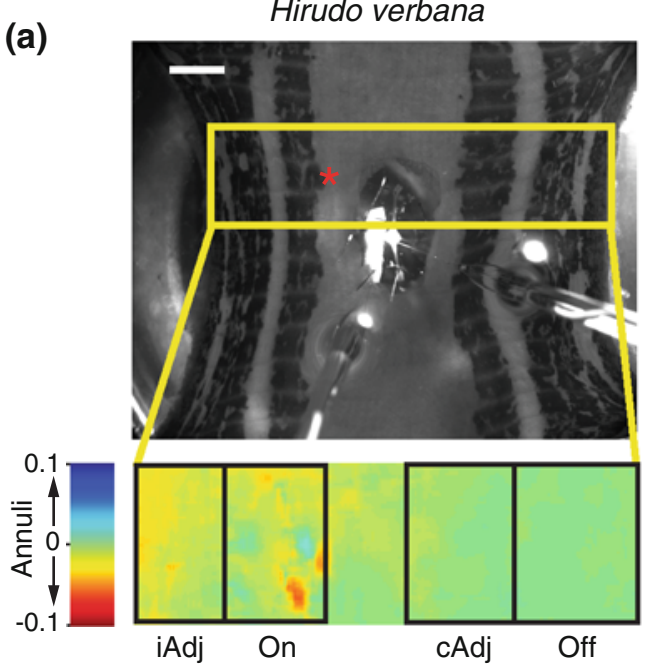

(b)

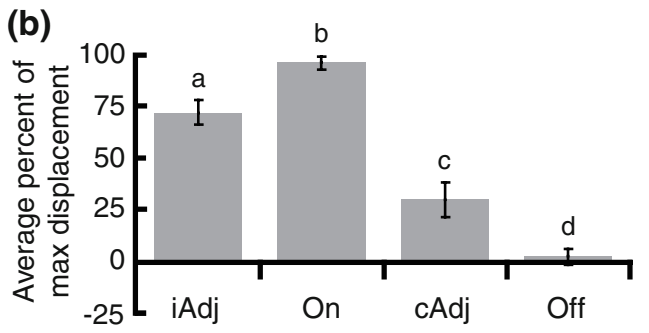

(c)
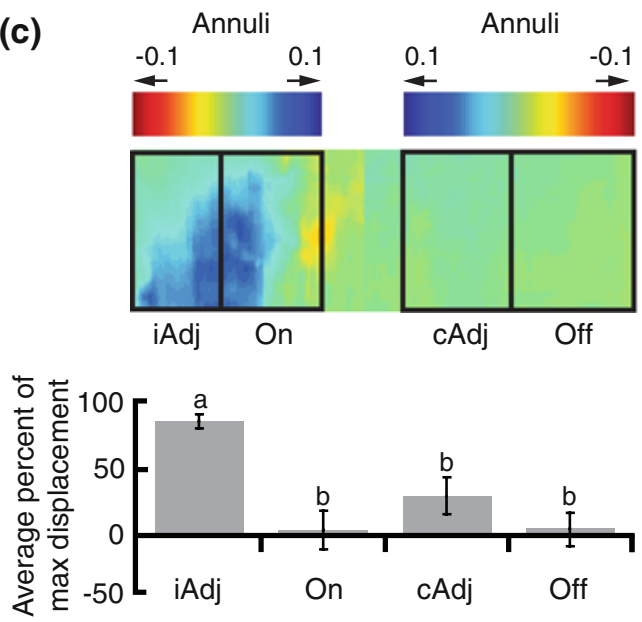

Fig. 8 Body wall movement due to intracellular stimulation of a P cell. a Top panels are video frames of Hirudo (left) and Erpobdella (right) before stimulation. The yellow box over the picture of the leech outlines the area of the body wall that was analyzed for motion. The red asterisks mark the middle of the receptive field of the stimulated $\mathrm{P}$ cell. The expanded colored rectangle indicates longitudinal movements of the region between 0 and $1 \mathrm{~s}$; cool colors (blue) indicate movement upward and warm colors (yellow-red) indicate movements downward. The black boxes on the expanded rectangle outline the regions used to compare body wall movements. 'On' is the body wall region corresponding to the receptive field of the stimulated P cell. 'iAdj', 'cAdj', and 'Off' are, respectively, the ipsilateral adjacent, contralateral adjacent, and contralateral non-adjacent body wall regions relative to the stimulated $\mathrm{P}$ cell. In these examples, the right $\mathrm{P}_{\mathrm{V}}$ in Hirudo and the left $\mathrm{P}_{\mathrm{V}}$ in Erpobdella were stimulated. The images for Erpobdella were reflected along the vertical axis to aid in comparing the two species. Scale bars $1 \mathrm{~mm}$. b Average magnitude of longitudinal body wall movement in
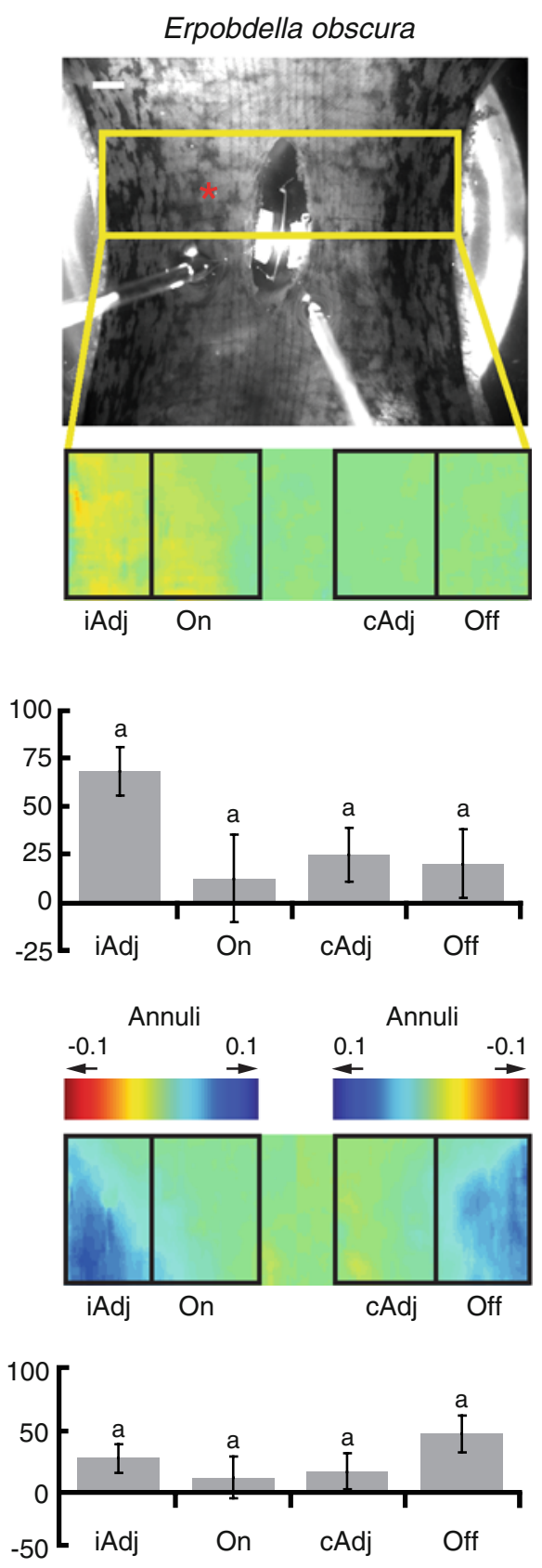

Hirudo (left; $n=11$ ) and Erpobdella (right; $n=10)$. The gray bars are the mean percentage of maximum displacement over the areas contained in the black boxes in a. The letter above each bar indicates significant differences between regions. The error bars indicate SEM. c The colored rectangle indicates lateral movements of the body wall between 0 and $1 \mathrm{~s}$; cool colors (blue) indicate movement toward the ventral midline and warm colors (yellow-red) indicate movements toward the dorsal midline. The black boxes on the expanded rectangle outline the regions used to compare body wall movements. The bottom panels are the average magnitude of lateral body wall movement in Hirudo (left; $n=11$ ) and Erpobdella (right; $n=10)$. The gray bars are the mean percentage of maximum displacement over the areas contained in the black boxes in the top panel. The letter above each bar indicates significant differences between regions. The error bars indicate SEM. On receptive field of the stimulated $\mathrm{P}$ cell, $i A d j$ receptive field of the ipsilateral and adjacent $\mathrm{P}$ cell, $c A d j$ receptive field of the contralateral and adjacent $\mathrm{P}$ cell, $O f f$ receptive field of the non-adjacent $\mathrm{P}$ cell 
Table 1 Summary of standardized body wall movement and statistical analysis when a P cell is stimulated
On Body wall region corresponding to the sensory field of the stimulated $\mathrm{P}$ cell, iAdj body wall region ipsilateral to the stimulated $\mathrm{P}$ cell, $c$ Adj region contralateral and adjacent to the stimulated P cell, Off non-adjacent region relative to the stimulated $\mathrm{P}$ cell

$P<0.05$ in bold

\begin{tabular}{|c|c|c|c|c|}
\hline & \multicolumn{2}{|l|}{ Longitudinal } & \multicolumn{2}{|l|}{ Lateral } \\
\hline & Hirudo & Erpobdella & Hirudo & Erpobdella \\
\hline \multicolumn{5}{|c|}{ Body wall movement $[\%$ max $($ mean \pm SEM $)]$} \\
\hline iAdj & $0.72 \pm 0.06$ & $0.68 \pm 0.13$ & $0.91 \pm 0.06$ & $0.29 \pm 0.12$ \\
\hline On & $0.96 \pm 0.03$ & $0.13 \pm 0.23$ & $0.04 \pm 0.15$ & $0.13 \pm 0.18$ \\
\hline cAdj & $0.30 \pm 0.09$ & $0.25 \pm 0.14$ & $0.31 \pm 0.15$ & $0.17 \pm 0.16$ \\
\hline Off & $0.02 \pm 0.04$ & $0.20 \pm 0.18$ & $0.05 \pm 0.13$ & $0.50 \pm 0.16$ \\
\hline$n$ & 11 & 10 & 11 & 10 \\
\hline \multicolumn{5}{|c|}{ Statistical analysis ( $P$ values) } \\
\hline ANOVA & $<0.0001$ & 0.12 & $<0.0001$ & 0.35 \\
\hline \multicolumn{5}{|l|}{$t$ test (paired) } \\
\hline iAdj vs. On & 0.002 & 0.06 & $<0.0001$ & 0.41 \\
\hline iAdj vs. cAdj & 0.004 & 0.05 & 0.001 & 0.53 \\
\hline iAdj vs. Off & $<0.0001$ & 0.12 & 0.0003 & 0.30 \\
\hline On vs. cAdj & 0.0002 & 0.70 & 0.28 & 0.80 \\
\hline On vs. Off & $<0.0001$ & 0.80 & 0.97 & 0.14 \\
\hline cAdj vs. Off & 0.004 & 0.77 & 0.07 & 0.12 \\
\hline
\end{tabular}

Even though the data suggest that the dorsal body wall movement was not affected by cutting the DP nerve, we nonetheless compared only the 'On' region to the 'cAdj' region in preparations where a $\mathrm{P}_{\mathrm{V}}$ was stimulated. In Hir$u d o$, the longitudinal movement in the two regions was significantly different $[\mathrm{On}($ mean $\pm \mathrm{SEM})=0.99 \pm 0.01$; $\mathrm{cAdj}=$ $0.33 \pm 0.05 ; t$ test: $P<0.00005 ; n=6$ ], while the lateral movement was not statistically different $(\mathrm{On}=0.12 \pm 0.14$; cAdj $=0.50 \pm 0.14 ; t$ test: $P=0.17$ ); in Erpobdella, neither the longitudinal $(\mathrm{On}=0.24 \pm 0.16 ; \mathrm{cAdj}=0.08 \pm$ 0.18 ; $t$ test: $P=0.85 ; n=6)$ nor lateral $(\mathrm{On}=0.17 \pm 0.06$; cAdj $=0.20 \pm 0.13$; $t$ test: $P=0.86)$ movement was significantly different between regions. These results are consistent with the results when all body regions are considered.

\section{Discussion}

Hirudo and Erpobdella have different responses to tactile stimulation (Figs. 1, 2). The behavioral responses of intact Hirudo and of isolated body wall from Hirudo have been well-studied (Kristan et al. 1982; Lockery and Kristan 1990a, b; Misell et al. 1998; Kristan et al. 2005). The local bending behavior we observed in both intact Hirudo (Fig. 1) and in isolated body wall preparations (Fig. 2) were consistent with previous reports of local bending (Baca et al. 2005, 2008; Thomson and Kristan 2006). In contrast, in response to tactile stimulation, Erpobdella responds with an even contraction across the segment, rather than an asymmetric contraction centered at the location of the stimulus (Fig. 2).

Sensory stimuli that elicit local bending in Hirudo activate one or more of the four mechanosensory $\mathrm{P}$ cells
(Kristan 1982; Lockery and Kristan 1990a; Lewis and Kris$\tan$ 1998a; Thomson and Kristan 2006; Baca et al. 2008). The $\mathrm{P}$ cells are easily identifiable based on their size, location, morphology and physiological properties. We identified neurons in E. obscura that are in the same location, have a similar size, and a similar morphology (Fig. 3). Additionally, we recorded the responses of putative T, $\mathrm{P}$, and $\mathrm{N}$ cells to body wall stimulation (Fig. 4). The physiological properties of these cells were similar to the T, P, and $\mathrm{N}$ cells in Hirudo and in other leech species (Nicholls and Baylor 1968; Johansen and Kleinhaus 1986; Lockery and Kristan 1990a; Lewis and Kristan 1998b; Burgin and Szczupak 2003). Therefore, we conclude that the putative T, P, and N cells in Erpobdella are homologous to the T, P and $\mathrm{N}$ cells in Hirudo.

The P cells in Hirudo have been studied extensively (Nicholls and Baylor 1968; Lewis and Kristan 1998a; Burgin and Szczupak 2003; Thomson and Kristan 2006), but the interactions between the $\mathrm{P}$ cells have not been thoroughly investigated. We found that a train of action potentials in one $\mathrm{P}$ cell caused a hyperpolarization in the other $\mathrm{P}$ cells (Figs. 5, 6). There was often a weak depolarization observed before the hyperpolarization (Fig. 5), similar to the connection between the P cells and the touch (T) mechanoreceptor cells in Hirudo (Burgin and Szczupak 2003).

Based on our results from experiments with a high divalent cation saline solution, we conclude that the $\mathrm{P}$ cells in Hirudo have an inhibitory polysynaptic chemical connection (Fig. 7). When we bathed the ganglion in a high $\mathrm{Mg}^{2+}$ low $\mathrm{Ca}^{2+}$ saline solution, the small depolarization still existed, indicating that it resulted from an electrical connection. It is possible that the high $\mathrm{Mg}^{2+} /$ low $\mathrm{Ca}^{2+}$ saline did 
not completely block the chemical synapse and the depolarization was due to a monosynaptic connection and not to an electrical connection. However, the high $\mathrm{Mg}^{2+} /$ low $\mathrm{Ca}^{2+}$ saline that we used has been used before to block chemical synapses in the sensory cells of Hirudo (Burgin and Szczupak 2003). Additionally, a previous study (Baylor and Nicholls 1969) reported that there are weak electrical connections between P cells, although data were not shown.

The net effect of the complex connections between $\mathrm{P}$ cells in Hirudo is that when one $\mathrm{P}$ cell is excited by a mechanical stimulus, it inhibits the other $\mathrm{P}$ cells. This lateral inhibition is consistent with the local bending behavior seen in Hirudo (Baca et al. 2005, 2008; Thomson and Kris$\tan$ 2006). It is also similar to the inhibitory interactions among adjacent sensory neurons seen in variety of sensory systems, including vision in vertebrates (Fahey and Burkhardt 2003), hair cells in the mammalian inner ear (Nobili et al. 1998), lateral line organs in fish (Müller 1996), statocysts in crayfish (Nakagawa and Hisada 1990), and mechanosensory sensilla in cockroaches (Hill and Blagburn 1998). It is worth noting that the inhibition between the $P$ cells may be used for localization of the behavioral response, while inhibition among the interneurons that mediate local bending is used for gain control (Baca et al. 2008). Therefore, inhibition onto different functional groups of neurons may serve different functions.

In contrast to Hirudo, the P cells in Erpobdella are mutually excitatory (Figs. 5, 6). When we bathed Erpobdella ganglia in a high $\mathrm{Mg}^{2+} /$ high $\mathrm{Ca}^{2+}$ solution, the EPSPs were greatly reduced. Additionally, when we exposed Erpobdella ganglia in a high $\mathrm{Mg}^{2+} / 0 \mathrm{Ca}^{2+}$ solution, the EPSPs were again reduced but not eliminated. This indicates that the excitation was due to polysynaptic chemical connections and electrical connections between the P cells (Fig. 7). There are many possible mechanisms that could account for the observed change from excitation to inhibition. For instance, the P cells could be exciting a different subset of interneurons in each species. Alternatively, the $\mathrm{P}$ cells could excite the same interneurons, but the interneurons could release different neurotransmitters in the two species, or the receptors on the P cells in Hirudo may differ from those in Erpobdella. Lastly, it is possible that both species have polysynaptic excitation and inhibition, but that the ratio of excitation to inhibition is different in the two species.

There is also a morphological difference between the $\mathrm{P}$ cells in Hirudo and the $\mathrm{P}$ cells in Erpobdella. The $\mathrm{P}_{\mathrm{V}}$ cells (Fig. 3) and the $P_{D}$ cells (Marin-Burgin et al. 2005) in Hirudo have 1-3 neurites that cross the midline of the ganglion. We did not find neurites that cross the midline from either $\mathrm{P}_{\mathrm{V}}$ or $\mathrm{P}_{\mathrm{D}}$ cells in Erpobdella. It is possible that this difference in cell morphology is related to the inhibitory polysynaptic connections between the $\mathrm{P}$ cells in Hirudo.
However, stimulating a P cell in Hirudo causes changes in the membrane potentials of 50-80 neurons within the same ganglion (Baca et al. 2008), so there are many possible interneurons that could mediate the inhibitory connection between the P cells. Additionally, just because these neurites have not been seen in Erpobdella does not mean they do not exist; they might be smaller or have other impediments to dye passage.

When we stimulated P cells with an intracellular electrode, we observed body wall contractions consistent with the behavior produced by a localized mechanical stimulus (Fig. 8). In Hirudo, stimulating a $\mathrm{P}$ cell results in strong ipsilateral longitudinal muscle contractions and weak contralateral contractions; in Erpobdella, the ipsilateral and contralateral longitudinal muscle contractions were not significantly different. The circular muscle contractions in Hir$u d o$ were also asymmetrical, with the strongest contractions occurring in the body wall region ipsilateral and adjacent to the site of stimulation. In Erpobdella, the circular muscle contractions were symmetrical: the ipsilateral and contralateral contractions not significantly different.

The segment-wide contraction in Erpobdella is similar to the circumferential indentation behavior seen during the embryonic development (ED) of Hirudo (Reynolds et al. 1998; Marin-Burgin et al. 2005). At about 55\% ED, mechanical stimulation causes Hirudo to generate circumferential indentation, a longitudinal contraction around the entire circumference of the stimulated segment. By $60 \%$ ED, the Hirudo embryo shows local bending behavior, with a longitudinal contraction on the side of the stimulation and relaxation on the opposite side. The behavioral change from circumferential indentation to local bending occurs when the electrical connections between motor neurons is replaced by inhibitory chemical synapses (Marin-Burgin et al. 2005). However, it is also possible that the inhibition between the $\mathrm{P}$ cells develops at the same time and contributes to the behavioral transition from circumferential indentation to local bending.

Although the tensing behavior in Erpobdella is consistent with the mutual excitability of the P cells, the observed behavioral differences between Hirudo and Erpobdella could result from at least three other differences: (1) the P cells might have larger receptive fields in Erpobdella so that a stimulus that recruits only one P cell in Hirudo may recruit several P cells in Erpobdella; (2) the N cells in Erpobdella might have a lower activation threshold than the $\mathrm{N}$ cells in Hirudo and may contribute to the observed behavioral responses; and (3) the connections between P cells and $\mathrm{T}$ cells may be excitatory in Erpobdella rather than inhibitory, as in Hirudo. Each of these alternative hypotheses is testable.

Because we only have data from two species, we cannot speculate as to whether the mutual inhibition between $\mathrm{P}$ 
cells in Hirudo or the mutual excitation between $\mathrm{P}$ cells in Erpobdella is the derived condition. Similarly, with only two species to compare it is difficult to attribute the evolutionary change in neural circuitry to a specific environmental factor. However, Hirudo and Erpobdella have two distinctly different life history features that could impact the role of mechanosensory information. While both species are freshwater leeches, Hirudo deposits its cocoons on land while Erpobdella deposits its cocoons in water (Borda and Siddall 2004a, b). During this brief terrestrial stage, Hirudo would experience different mechanosensory stimulation than it would experience in an aquatic environment. Additionally, while Hirudo typically feeds on mammalian and amphibian blood, Erpobdella preys on a variety of aquatic invertebrates (Mann 1955; Davies et al. 1978). These different life history strategies could put different selective pressures on the mechanosensory input of Erpobdella and Hirudo (Gaudry et al. 2010). A more extensive survey of the interactions between the mechanosensory cells in leeches is necessary before we can begin to understand the ecological factors that shape mechanosensory processing in these animals.

Regardless of the types of selective pressure that shape mechanosensory processing in Hirudo and Erpobdella, the differences between the species indicate that the neural circuitry is evolutionarily labile. Previous studies have found that the function of neural circuits can evolve by changing neuromodulators (Fenelon et al. 2004), changing neuron physiological properties (Newcomb and Katz 2007), adding neurons (Page 2002; Baltzley and Lohmann 2008), losing neurons (Espinoza et al. 2006), changing neuron structures (Dacks et al. 2006), and changing synaptic strengths (Chiang et al. 2006). Therefore, it is not surprising that neural circuits could also evolve by changing from an excitatory chemical connection to an inhibitory one. This phenomenon may in fact be a common strategy in the evolution of nervous systems, but it has not been previously demonstrated in identified neurons.

The mechanosensory neurons in leeches may be an ideal system to study the evolution of neural circuits for several reasons. First, the phylogeny of leeches is well-studied (Siddall et al. 2001, 2005; Siddall 2002; Borda and Siddall 2004 b), so there is already a solid framework on which to map changes in neural circuits. Secondly, the nervous system is highly conserved across the leeches, so homologs to the mechanosensory neurons of Hirudo are easily identifiable in many other leeches (Kramer and Goldman 1981; Kramer and Stent 1985; Nusbaum 1986; Elsas et al. 1995). Third, because the mechanosensory cells have already been well-characterized in Hirudo (Lewis and Kristan 1998a; Thomson and Kristan 2006; Baca et al. 2008), there are numerous properties of the sensory system - the sensitivity and receptive fields of the sensory neurons, their connections to one another, to interneurons and to motor neurons- that can be compared across species.

Acknowledgments We thank K. L. Todd and D. A. Wagenaar for assistance with the optical flow data analysis. We thank N. Ruiz and $\mathrm{T}$. Huang for assistance with the intact leech behavioral data collection. We thank R. Myerowitz and J. U. Ramcharitar for loaning equipment and lab space. We thank K. A. French for advice and comments on the work and manuscript. We thank the members of the laboratory of K. A. Mesce for assistance in collecting Erpobdella obscura. This work was funded by grants from the National Institutes of Health (MH43396, NS35336, and NS07229) to W. B. Kristan and the National Science Foundation (IOB-0523959) to W. B. Kristan and K. A. Mesce.

Open Access This article is distributed under the terms of the Creative Commons Attribution Noncommercial License which permits any noncommercial use, distribution, and reproduction in any medium, provided the original author(s) and source are credited.

\section{References}

Antonsen BL, Herberholz J, Edwards DH (2005) The retrograde spread of synaptic potentials and recruitment of presynaptic inputs. J Neurosci 25:3086-3094

Baca SM, Thomson EE, Kristan WB Jr (2005) Location and intensity discrimination in the leech local bend response quantified using optic flow and principal components analysis. J Neurophysiol 93:3560-3572

Baca SM, Marin-Burgin A, Wagenaar DA, Kristan WB Jr (2008) Widespread inhibition proportional to excitation controls the gain of a leech behavioral circuit. Neuron 57:276-289

Baltzley MJ, Lohmann KJ (2008) Comparative study of TPep-like immunoreactive neurons in the central nervous system of nudibranch molluscs. Brain Behav Evol 72:192-206

Baylor DA, Nicholls JG (1969) Chemical and electrical synaptic connexions between cutaneous mechanoreceptor neurones in central nervous system of leech. J Physiol (Lond) 203:591-609

Beenhakker MP, Blitz DM, Nusbaum MP (2004) Long-lasting activation of rhythmic neuronal activity by a novel mechanosensory system in the crustacean stomatogastric nervous system. J Neurophysiol 91:78-91

Borda E, Siddall ME (2004a) Review of the evolution of life history strategies and phylogeny of the Hirudinida (Annelida: Oligochaeta). Lauterbornia 52:5-25

Borda E, Siddall ME (2004b) Arhynchobdellida (Annelida: Oligochaeta: Hirudinida): phylogenetic relationships and evolution. Mol Phylogenet Evol 30:213-225

Breidbach O, Kutsch W (1995) Introductory remarks. In: Breidbach O, Kutsch W (eds) The nervous system of invertebrates: an evolutionary and comparative approach. Birkhauser Verlag, Basel, pp 1-6

Burgin AM, Szczupak L (2003) Network interactions among sensory neurons in the leech. J Comp Physiol A 189:59-67

Cauna N, Ross LL (1960) The fine structure of Meissners touch corpuscles of human fingers. J Bioph Biochem Cytol 8:467-482

Chiang JTA, Steciuk M, Shtonda B, Avery L (2006) Evolution of pharyngeal behaviors and neuronal functions in free-living soil nematodes. J Exp Biol 209:1859-1873

Croll RP (1987) Identified neurons and cellular homologies. In: Ali MA (ed) Nervous systems in invertebrates. Plenum Press, New York, pp 41-59

Dacks AM, Christensen TA, Hildebrand JG (2006) Phylogeny of a serotonin-immunoreactive neuron in the primary olfactory center of the insect brain. J Comp Neurol 498:727-746 
Davies RW, Wrona FJ, Everett RP (1978) A serological study of prey selection by Nephelopsis obscura Verrill (Hirudinoidea). Can J Zool 56:587-591

Elsas SM, Kwak EM, Stent GS (1995) Acetylcholine-induced retraction of an identified axon in the developing leech embryo. J Neurosci 15:1419-1436

Espinoza SY, Breen L, Varghese N, Faulkes Z (2006) Loss of escaperelated giant neurons in a spiny lobster, Panulirus argus. Biol Bull 211:223-231

Fahey PK, Burkhardt DA (2003) Center-surround organization in bipolar cells: symmetry for opposing contrasts. Vis Neurosci 20:1-10

Fenelon VS, Le Feuvre Y, Meyrand P (2004) Phylogenetic, ontogenetic and adult adaptive plasticity of rhythmic neural networks: a common neuromodulatory mechanism? J Comp Physiol A 190:691-705

Gaudry Q, Ruiz N, Huang T, Kristan WB III, Kristan WB Jr (2010) Behavioral choice across leech species: chacun à son gout. J Exp Biol (in press)

Hill ES, Blagburn JM (1998) Indirect synaptic inputs from filiform hair sensory neurons contribute to the receptive fields of giant interneurons in the first-instar cockroach. J Comp Physiol A 183:467-476

Hustert R, Lodde E, Gnatzy W (1999) Mechanosensory pegs constitute stridulatory files in grasshoppers. J Comp Neurol 410:444-456

Johansen J, Kleinhaus AL (1986) Differential sensitivity of tetrodotoxin of nociceptive neurons in 4 species of leeches. J Neurosci 6:349-3504

Katz PS, Fickbohm DJT, Lynn-Bullock CP (2001) Evidence that the central pattern generator for swimming in Tritonia arose from a non-rhythmic neuromodulatory arousal system: implications for the evolution of specialized behavior. Am Zool 41:962-975

Keyser KT, Frazer BM, Lent CM (1982) Physiological and anatomical properties of Leydig cells in the segmental nervous system of the leech. J Comp Physiol 146:379-392

Kindt KS, Viswanath V, Macpherson L, Quast K, Hu HZ, Patapoutian A, Schafer WR (2007) Caenorhabditis elegans TRPA-1 functions in mechanosensation. Nat Neurosci 10:568-577

Kramer AP, Goldman JR (1981) The nervous system of the glossiphoniid leech Haementeria ghilianii. 1. Identification of neurons. J Comp Physiol 144:435-448

Kramer AP, Stent GS (1985) Developmental arborization of sensory neurons in the leech Haementeria ghilianii. 2. Experimentally induced variations in the branching pattern. J Neurosci 5:768-775

Kramer AP, Goldman JR, Stent GS (1985) Developmental arborization of sensory neurons in the leech Haementeria ghilianii. 1. Origin of natural variations in the branching pattern. J Neurosci 5:759-767

Kristan WB Jr (1982) Sensory and motor neurons responsible for the local bending response in leeches. J Exp Biol 96:161-180

Kristan WB Jr, Stent GS, Ort CA (1974) Neuronal control of swimming in medicinal leech. 1. Dynamics of swimming rhythm. J Comp Physiol 94:97-119

Kristan WB Jr, McGirr SJ, Simpson GV (1982) Behavioral and mechanosensory neuron responses to skin stimulation in leeches. J Exp Biol 96:143-160

Kristan WB Jr, Calabrese RL, Friesen WO (2005) Neuronal control of leech behavior. Prog Neurobiol 76:279-327

Kutschera U (2006) The infamous bloodsuckers from Lacus Verbanus. Lauterbornia 56:1-4

Lent CM, Frazer BM (1977) Connectivity of monoamine-containing neurones in central nervous system of leech. Nature 266:844-847

Lewis JE, Kristan WB (1998a) Quantitative analysis of a directed behavior in the medicinal leech: implications for organizing motor output. J Neurosci 18:1571-1582

Lewis JE, Kristan WB (1998b) Representation of touch location by a population of leech sensory neurons. J Neurophysiol 80:25842592
Lockery SR, Kristan WB Jr (1990a) Distributed processing of sensory information in the leech. I. Input-output relations of the local bending reflex. J Neurosci 10:1811-1815

Lockery SR, Kristan WB Jr (1990b) Distributed processing of sensory information in the leech. II. Identification of interneurons contributing to the local bending reflex. J Neurosci 10:1816-1829

Mann KH (1955) The ecology of the British freshwater leeches. J Anim Ecol 24:98-119

Marin-Burgin A, Eisenhart FJ, Baca SM, Kristan WB Jr, French KA (2005) Sequential development of electrical and chemical synaptic connections generates a specific behavioral circuit in the leech. J Neurosci 25:2478-2489

Misell LM, Shaw BK, Kristan WB Jr (1998) Behavioral hierarchy in the medicinal leech, Hirudo medicinalis: feeding as a dominant behavior. Behav Brain Res 90:13-21

Müller HM (1996) Indications for feature detection with the lateral line organ in fish. Comp Biochem Physiol 114A:257-263

Nakagawa H, Hisada M (1990) Inhibitory connections underlying the directional sensitivity of the equilibrium system in the crayfish Procambarus clarkii. J Exp Biol 152:305-312

Newcomb JM, Katz PS (2007) Homologs of serotonergic central pattern generator neurons in related nudibranch molluscs with divergent behaviors. J Comp Physiol A 193:425-443

Nicholls JG, Baylor DA (1968) Specific modalities and receptive fields of sensory neurons in CNS of leech. J Neurophysiol 31:740-756

Nobili R, Mammano F, Ashmore J (1998) How well do we understand the cochlea? Trends Neurosci 21:159-167

Nusbaum MP (1986) Synaptic basis of swim initiation in the leech. III. Synaptic effects of serotonin containing interneurons (cell 21 and cell 61) on swim CPG neurons (cells 18 and 208). J Exp Biol 122:303-321

Nusbaum MP, Kristan WB Jr (1986) Swim initiation in the leech by serotonin-containing interneurons, cell 21 and cell 61. J Exp Biol 122:277-302

Nusbaum MP, Friesen WO, Kristan WB Jr, Pearce RA (1987) Neural mechanisms generating the leech swimming rhythm: swim-initiator neurons excite the network of swim oscillator neurons. J Comp Physiol A 161:355-366

Page LR (2002) Comparative structure of the larval apical sensory organ in gastropods and hypotheses about function and developmental evolution. Invertebr Reprod Dev 41:193-200

Peterson DL (1983) Life cycle and reproduction of Nephelopsis obscura Verrill (Hirudinea: Erpobdellidae) in permanent ponds of Northwestern Minnesota. Freshw Invertebr Biol 2:165-172

Phillips AJ, Siddall ME (2009) Poly-paraphyly of Hirudinidae: many lineages of medicinal leeches. BMC Evol Biol 9:246-256

Puhl JG, Mesce KA (2008) Dopamine activates the motor pattern for crawling in the medicinal leech. J Neurosci 28:4192-4200

Reynolds SA, French KA, Baader A, Kristan WB Jr (1998) Development of spontaneous and evoked behaviors in the medicinal leech. J Comp Neurol 402:168-180

Rodriguez MJ, Iscla IR, Szczupak L (2004) Modulation of mechanosensory responses by motoneurons that regulate skin surface topology in the leech. J Neurophysiol 91:2366-2375

Siddall ME (2002) Phylogeny of the leech family Erpobdellidae (Hirudinida: Oligochaeta). Invertebr Syst 16:1-6

Siddall ME, Apakupakul K, Burreson EM, Coates KA, Erseus C, Gelder SR, Kallersjo M, Trapido-Rosenthal H (2001) Validating Livanow: molecular data agree that leeches, branchiobdellidans, and Acanthobdella peledina form a monophyletic group of oligochaetes. Mol Phylogenet Evol 21:346-351

Siddall ME, Budinoff RB, Borda E (2005) Phylogenetic evaluation of systematics and biogeography of the leech family Glossiphoniidae. Invertebr Syst 19:105-112

Siddall ME, Trontelj P, Utevsky SY, Nkamany M, Macdonald KS (2007) Diverse molecular data demonstrate that commercially 
available medicinal leeches are not Hirudo medicinalis. Proc R Soc B 274:1481-1487

Stern-Tomlinson W, Nusbaum MP, Perez LE, Kristan WB Jr (1986) A kinematic study of crawling behavior in the leech, Hirudo medicinalis. J Comp Physiol A 158:593-603

Suzuki M, Watanabe Y, Oyama Y, Mizuno A, Kusano E, Hirao A, Ookawara S (2003) Localization of mechanosensitive channel TRPV4 in mouse skin. Neurosci Lett 353:189-192

Thomson EE, Kristan WB Jr (2006) Encoding and decoding touch location in the leech CNS. J Neurosci 26:8009-8016

Watson WH, Willows AOD (1992) Evidence for homologous peptidergic neurons in the buccal ganglia of diverse nudibranch mollusks. J Neurobiol 23:173-186
Weiss KR, Kupfermann I (1976) Homology of giant serotonergic neurons (metacerebral cells) in Aplysia and pulmonate molluscs. Brain Res 117:33-49

Wilkin PJ, Scofield AM (1991) The structure of a natural population of the medicinal leech, Hirudo medicinalis, at Dungeness, Kent. Freshw Biol 25:539-546

Wright WG, Kirschman D, Rozen D, Maynard B (1996) Phylogenetic analysis of learning-related neuromodulation in molluscan mechanosensory neurons. Evolution 50:2248-2263

Zar JH (1999) Biostatistical analysis. Prentice Hall, Upper Saddle River, pp 273-281 